\title{
6-1-1974
}

\section{Some Reflections on the State Taxation of a Nonresident's Personal Income}

Walter Hellerstein

University of Georgia School of Law, wallyh@uga.edu

DSPRN

\section{Repository Citation}

Walter Hellerstein, Some Reflections on the State Taxation of a Nonresident's Personal Income (1974), Available at: https://digitalcommons.law.uga.edu/fac_artchop/314

This Article is brought to you for free and open access by the Faculty Scholarship at Digital Commons @ University of Georgia School of Law. It has been accepted for inclusion in Scholarly Works by an authorized administrator of Digital Commons @ University of Georgia School of Law. Please share how you have benefited from this access For more information, please contact tstriepe@uga.edu. 


\title{
SOME REFLECTIONS ON THE STATE TAXATION OF A NONRESIDENT'S PERSONAL INCOME
}

\author{
Walter Hellerstein*
}

\section{INTRODUCTION}

$\mathrm{T}$ HE doctrinal ferment that permeated the constitutional law of state taxation in the $1930^{\prime} \mathrm{s}^{1}$ evoked an impressive outpouring of scholarly commentary. ${ }^{2}$ Detailed consideration was given to questions of situs, domicile, and jurisdiction to tax; ${ }^{3}$ to distinctions between subject, rate, and measure; ${ }^{4}$ and to the nature of tangibles, intangibles, and income. ${ }^{5}$ Judicial opinions were dissected, ${ }^{6}$ legal fictions were discredited, ${ }^{7}$ and ameliorative proposals, theoretical and practical, were advanced. ${ }^{8}$ The Supreme Court signaled the end to much of this conceptual unrest and commentary by resolving many of the issues in definitive, ${ }^{9}$ if somewhat inequitable, ${ }^{10}$ terms. With

- Member of the District of Columbia Bar. A.B. 1967, Harvard University; J.D. 1970, University of Chicago.-Ed.

1. Compare Farmers Loan \& Trust Co. v. Minnesota, 280 U.S. 204 (1930), and First Natl. Bank v. Maine, 284 U.S. 312 (1932) (due process clause forbids "double taxation" of intangibles) with Graves v. Elliott, 307 U.S. 383 (1939), and Curry v. McCanless, 307 U.S. 357 (1939) (due process clause no bar to "double taxation" of intangibles). See also Pearson v. McGraw, 308 U.S. 313 (1939); Guaranty Trust Co. v. Virginia, 305 U.S. 19 (1938); First Bank Stock Corp. v. Minnesota, 301 U.S. 234 (1937); New York ex rel. Cohn v. Graves, 300 U.S. 308 (1937); Wheeling Steel Corp. v. Fox, 298 U.S. 193 (1936); Senior v. Braden, 295 U.S. 422 (1935); Virginia v. Imperial Coal Sales Co., 293 U.S. 15 (1934); Lawrence v. State Tax Commn., 286 U.S. 276 (1932).

2. See, e.g., the articles cited in notes 3-8 infra.

3. See Merrill, Jurisdiction To Tax-Another Word, 44 YALE L.J. 582 (1935); Tweed 8. Sargent, Death and Taxes Are Certain-But What of Domicile, 53 HARv. L. Rev, 68 (1939).

4. See Lowndes, Rate and Measure in Jurisdiction To Tax-Aftermath of Maxwell v. Bugbee, 49 HARv. L. REv. 756 (1936); Rodell, A Primer on Interstate Taxation, 44 YALE L.J. 1166 (1935).

5. See Bittker, The Taxation of Out-of-State Tangible Property, 56 YALE L.J. 640 (1947); Nossaman, The Fourteenth Amendment in Its Relation to State Taxation of Intangibles, 18 CALrF. L. REv. 345 (1930); Rottschaefer, State Jurisdiction of Income for Taxi Purposes, 44 HaRv. L. Rev. 1075 (1931).

6. See Lowndes, The Tax Decisions of the Supreme Court, 1938 Term, 88 U. PA. L. Rev. I (1939); Traynor, State Taxation and the Supreme Court, 1938 Term, 28 CAIIF. L. REv. 1 (1939).

7. See Guterman, Revitalization of Multiple State Death Taxation, 42 Colum. L. REv. 1249 (1942); Lowndes, Spurious Conceptions of the Constitutional Law of Taxation, 47 HARv. L. REv. 628 (1934).

8. See Farage, Multiple Domicils and Multiple Inheritance Taxes-A Possible Solution, 9 Gro. WASH. L. REv. 375 (1941); Hellerstein \& Hennefeld, State Taxation in a National Economy, 54 HARv. L. REv. 949 (1941).

9. See Curry v. McCanless, 307 U.S. 357 (1939) (due process clause no bar to "double" death taxation of intangibles); Guaranty Trust Co. v. Virginia, 305 U.S. 19 (1938) (due

$$
\text { [1309] }
$$


the governing principles more or less established, at least to the satisfaction of those who might be motivated to write about them, the business of interpreting and implementing state property, death, and personal income taxes was left largely to the state courts and the state legislatures. ${ }^{11}$

With respect to the taxation of personal income, it was plain by 1940 that states were constitutionally free to tax residents on all personal income wherever earned ${ }^{12}$ and nonresidents on personal income earned within the state, ${ }^{13}$ even though these two principles, taken together, meant that an individual's income might be subject to "double-taxation" by different states. ${ }^{14}$ The Court, after toying with the idea for a decade, ${ }^{15}$ finally rejected the invitation to forge the due process clause into a tool for preventing multiple taxation ${ }^{10}$ and reverted to the ruling law of an earlier $\operatorname{era}^{17}$ that left the solution of such problems to the collective wisdom of the states.

process clause no bar to "double" income taxation); Frick v. Pennsylvania, 268 U.S. 473 (1925); Union Refrigerator Transit Co. v. Kentucky, 199 U.S. 194 (1905) (rcal property and tangible personalty taxable under death and property tax laws only by states in which located).

10. The Court itself had reservations concerning the impact of its decisions permitting multiple state taxation of the same income or intangibles. "If we enjoyed the freedom of the framers it is possible that we might, in the light of experience, devise a more equitable system of taxation than that which they gave us." Curry v. McCanless, 307 U.S. 357, 373 (1939).

11. The same cannot be said with reference to state taxation of businesses, where cases continued to be bitterly fought for the next three decades over due process and commerce clause restrictions on state income, sales, and use taxes. See generally J. Hellerstein, State and Local Taxation pts. 4 \& 5 (3d ed. 1969); Developments in the Law-Federal Limitations on State Taxation of Interstate Business, 75 Harv. $\mathrm{L}$. REv. 953 (1962).

12. New York ex rel. Cohn v. Graves, 300 U.S. 308 (1937); Lawrence v. State Tax Commn., 286 U.S. 276 (1932); Maguire v. Trefry, 253 U.S. 12 (1920).

13. Travis v. Yale \& Towne Mfg. Co., 252 U.S. 60 (1920); Shaffer v. Carter, 252 U.S. 37 (1920).

Throughout this article, the term "resident" is used broadly to include the various concepts associated with the definition of a resident for state tax purposes, such as domicile, presence in the state for other than a temporary purpose or for a specified period of time, and maintenance of a permanent place of abode in the state. Sec G. Altman \& F. Keesuing, Allocation of Income in State Taxation 43 (2d ed. 1950); the term "nonresident" is used to mean an individual other than a resident. In any particular case, of course, the precise meaning of the terms "resident" and "nonresident" depends on the definition set out in a state's tax statute. See Note, Multistatc Taxation of Personal Income, 111 U. PA. L. REv. 974, 975-79 (1963).

14. Guaranty Trust Co. v. Virginia, 305 U.S. 19 (1938); Hughes v. Wisconsin Tax Commn., 227 Wis. 274, 278 N.W. 403, appeal dismissed, 304 U.S. 548 (1938).

15. See cases cited in note I supra.

16. See Guaranty Trust Co. v. Virginia, 305 U.S. 19, 23 (1938); Curry v. McCanless, 307 U.S. 357, 372-74 (1937).

17. See, e.g., Bullen v. Wisconsin, 240 U.S. 625 (1916); Blackstone v. Miller, 188 U.S. 189 (1903). 
As their need for revenue increased, a growing number of states turned to or relied more heavily upon the personal income tax as a revenue source. ${ }^{18}$ To the extent that the states' power to tax personal income was not limited by any constitutional proscription against multiple taxation, fairness to the individual taxpayer depended on the states' self-restraint-or enlightened self-interest ${ }^{19}$ - in refraining from exercising their taxing powers to constitutional limits ${ }^{20}$ or in granting credits for taxes paid to other states. ${ }^{21}$ Despite the absence of any formal interstate agreement designed to achieve greater uniformity and equity in the multistate taxation of personal income, ${ }^{22}$ the burden on the individual whose income is taxable by more than one state has been reduced over the years. ${ }^{23}$ Nevertheless, the tax status of the multistate taxpayer today is often characterized by uncertainty, unfairness, and considerable confusion. ${ }^{24}$

18. While a number of states enacted income taxes during the nineteenth century, see J. HeILERSTEIN, supra note 11 , at 59, they were generally abandoned due to administrative difficulties. See Rottschaefer, supra note 5, at 1075. The "modern revival" of the income tax began with the adoption of the Wisconsin income tax in 1911. Id. at 1075. Today between forty and forty-five states impose personal income taxes-the precise figure depends on whether one includes those states that impose their levy on only a limited category of income or taxpayers. See authorities cited in notes 120-26 infra, and accompanying text. Over the years, the states have generally raised the rates of their personal income taxes. Compare, e.g., U.S. Bureau of the Census, Statisticat Adstract of the UnIted States, State Individual Income TAXes: 1972, at 429 (1973) with U.S. Bureau of the Census, Statistical Abstract of the Untred States, State INDIVIDUAL INCOME TAXES: 1962, at 430 (1963).

19. See Starr, Reciprocal and Retaliatory Legislation in the American States, 21 MinN. L. REv. 371 (1937).

20. See Iowa Code ANn. § 422.8(2) (Supp. 1973); MINN. Stat. ANn. § 290.081 (Supp. 1974); Wrs. Stat. ANN. \& 71.03(2)(c) (1969) (all excluding nonresident personal service income from taxation if state of residence offers reciprocal exclusion).

21. E.g., GaL. REv. \& TAX Code § 18001 (1970); N.Y. TAX LAW § 620 (1966); VA. CODE ANN. \& 58-151.015 (Supp. 1973).

22. There is such an agreement with respect to the multistate taxation of business income. Over thirty-five states are members or associate members of the Multistate Tax Compact, P-H State and Local Taxes (All States Unit) II 5150-51 (1971). Article III of the Compact gives the multistate taxpayer the option to apportion and allocate his income with reference to state law or with reference to Article IV of the Multi-State Compact, reproduced in id., II 6310-68, which adopts practically verbatim the Uniform Division of Income for Tax Purposes Act, a proposal worked out by state tax administrators, lawyers, and accountants, aimed at achieving greater uniformity in state taxation of interstate commerce.

23. Note, supra note 13 , at 993 .

24. Although an individual's state tax problems do not usually make headlines, there was a notable recent exception: "The official says Mr. Nixon has considered himself a California resident throughout his presidency. . . However, Mr. Nixon's principal attorney in the White House negotiations with the [California] Franchise Tax Board says that he still takes the position that the President is not a resident 'for income tax purposes.' "Washington Post, Jan. 12, 1974, at 1, col. 3. The Franchise Tax Board agreed with Nixon's contention, ruling that he and Mrs. Nixon were not California residents for state income tax purposes. N.Y. Times, Feb. 2, 1974, at 12, col. 3 (late city ed.). The decision, however, "drew an immediate dissent" from a member 
It is within this framework that an intriguing and troublesome issue involving state taxation of personal income has recently arisen. Ironically, it grew out of an effort by one state, Vermont, to introduce what in its view was probably a greater degree of "equality" than had previously existed between its resident and nonresident taxpayers. What Vermont did, in effect, was this: In determining the rate at which a resident or nonresident taxpayer would pay tax on his Vermont income, the taxpayer's "ability to pay," on which Vermont's progressive rates were predicated, ${ }^{25}$ was reckoned by looking to all of his income wherever earned. ${ }^{23}$ The result, in principle at least, was to tax resident and nonresident taxpayers with the same federal taxable income at the same rate on their income taxable by Vermont. On its face, this does not seem unfair. From a constitutional perspective, it hardly presents a problem with respect to the Vermont resident because Vermont indisputably possesses the right to tax such income ${ }^{27}$ and a fortiori has the right to use it to determine the tax rate. With respect to the nonresident, however, the question is more complex. While it is clear that Vermont may properly insist that the nonresident pay tax on his Vermont-earned income, ${ }^{28}$ it is just as clear that Vermont has no jurisdiction to tax the nonresident's non-Vermont income. ${ }^{29}$ This raises the question whether taking such nontaxable income into account in determining the rate at which the nonresident's taxable Vermont income will be assessed achieves indirectly what may not constitutionally be achieved directly.

Perhaps it does. Over fifty years ago, however, the Supreme Court

of the California State Board of Equalization, another tax agency. Id. Moreover, the ruling left open the question whether any of Nixon's income that may have been de. rived from California was taxable by the state. Id. The Franchise Tax Board subscquently ruled that Nixon had incurred California tax liability for income earned in California. Washington Post, April 13, 1974, at 1, col. 8.

25. Indeed, the Vermont legislature has made this explicit: "It is intended that, for any taxable year, individuals, estates and trusts shall be taxed upon only their Vermont income for that year, but that the rate at which the Vermont income of any taxpayer is taxed under this chapter shall reflect the taxpayer's ability to pay as measured by his adjusted gross income for the taxable year." VT. STAT. AnN. tit. 32, $\S 5820(\mathrm{~b})(1970)$.

26. Vx. STAT. ANN. tit. 32 , § 5822 (1970).

27. See cases cited in note 12 supra.

28. See cases cited in note 13 supra; Nonresident Taxpayers Assn. v. Philadelphia, 341 F. Supp. 1139 (D.N.J. 1971), affd. mem., 406 U.S. 951 (1972).

29. State v. Burnett, 200 Ark. 655, 140 S.W.2d 673 (1940); People ex rel. Monjo v. State Tax Commn., 218 App. Div. 1, 217 N.Y.S. 669 (1926); Greene v. Wisconsin Tax Commn., 221 Wis. 531, 266 N.W. 270 (1936). The paucity of direct authority for this proposition no doubt arises from the fact that states have generally confined the taxation of nonresidents' income to that from local sources. Rottschaefer, supra note 5 , at 1080. 
decided in Maxwell v. Bugbee $e^{30}$ that such a method for establishing the rate of a death tax suffered from no constitutional infirmity, despite Justice Holmes's dissenting observation for himself and three others that "when property outside the State is taken into account for the purpose of increasing the tax upon property within it, the property outside is taxed in effect, no matter what form of words may be used." 31 While a number of states have taken advantage of Maxwell to employ a comparable formula for establishing the rate of a nonresident's estate or inheritance taxes, ${ }^{32}$ only three states other than Vermont $t^{33}$ have done so with respect to the taxation of a nonresident's income. Perhaps the reluctance stems from a prevailing sentiment in state legislatures that there is something inequitable about such an exaction; ${ }^{34}$ perhaps from neglect; perhaps from some other cause. ${ }^{35}$ In any case, Vermont's personal income tax statute raises in a contemporary context some of the fascinating and disturbing problems with which courts and commentators struggled in the 1930's and provides a useful vehicle for examining the scope of state taxing pówer over a nonresident's personal income.

My purpose here is fourfold: first, to inquire into the theoretical and constitutional underpinning of Vermont's taxing scheme against the background of the case that challenged the validity of the levy; second, to analyze the impact of related legislation on the principles upon which the basic Vermont formula was constructed; third, to determine whether there are reasons of law or policy why other states should not adopt schemes similar to Vermont's; and, fourth, to consider in light of the foregoing some of the recurring problems concerning the treatment of nonresidents under state income tax statutes.

\section{The Vermont Scheme-I}

Wilfred Wheeler made his home in Enfield, New Hampshire. ${ }^{36}$ He was employed as a salesman by Ward Foods, Inc., of White River

30. 250 U.S. 525 (1919).

31. 250 U.S. at 544 . The Supreme Court reaffirmed the vitality of the principle in Great Atl. \& Pac. Tea Co. v. Grosjean, 301 U.S. 412 (1937).

32. See note 137 infra and accompanying text.

33. Mo. Rev. Stat. ANn. § 143.041 (Supp. 1974); Neb. Rev. Stat. \& 77-2715(1) (Supp. 1973); R.I. GEN. LAws ANN. § 44-30-33 (Supp. 1972). See note 139 infra for a discussion of the former practice of territorial Alaska.

34. A number of years ago Professor Lowndes stated that "[i] $t$ is difficult . . . to imagine anything more iniquitously unfair than the application of the Maxwell formula to income taxation in the present state of the decisions on state jurisdiction to tax income." Lowndes, supra note 4 , at 770.

35. See Part IV infra.

36. Wheeler v. State, 127 Vt. 361,249 A.2d 887, appeal dismissed, 396 U.S. 4 (1969). 
Junction, Vermont, fifteen miles from Enfield. In soliciting orders for Ward Foods from retail food outlets Wheeler made frequent journeys across the Connecticut River, earning a substantial proportion of his sales commissions from sales to Vermont customers; in 1966, one quarter of his earnings, which consisted entirely of sales commissions, represented compensation earned in Vermont. By 1968, the proportion of Wheeler's earnings attributable to his Vermont activities had risen to thirty per cent. ${ }^{37}$

By joining the growing ranks of states that have adopted a fed. erally based state income tax, ${ }^{38}$ Vermont made it relatively easy for a nonresident like Wheeler to determine his Vermont income tax liability. The basic taxing provision reads:

A tax is imposed for each calendar year or fiscal year ending during that calendar year upon the Vermont income earned or received in that taxable year by every individual, estate and trust. The amount of this tax shall be measured by 25 per cent of the federal income tax liability of the taxpayer for the taxable year, reduced by a percentage equal to the percentage of the taxpayer's adjusted gross income for the taxable year which is not Vermont income.30

37. Wheeler v. State, 127 Vt. 499, 253 A.2d 136, appeal dismissed, 396 U.S. 4 (1969). The basic constitutional issue raised by the two Wheeler cases was identical. $127 \mathrm{Vt}$. at 501,253 A.2d at 138. The principal difference between the two cases was the tax year involved: The first decision concerned 1966, 127 Vt. 361, 249 A.2d 887, while the second concerned 1968. $127 \mathrm{Vt}$. 499, $253 \mathrm{~A} .2 \mathrm{~d}$ 136. In the interim, however, Vermont had amended its income tax law, substituting a federally based income tax employing the federal progressive rates for the progressive Vermont schedule previously employed. VT. Stat. ANN. tit. 32, §§ 5812-14, 5816-21, 5824-25, 5828, 5831-32, 5834-43, 5845-61, 5863-71, 5873-80, 5882-83, 5887, 5889-94 (1970), 5811, 5815, 5822-23, 5828a-30, 5833, $5844,5862,5872,5881,5884-86,5888,5895$ (Supp. 1973). The second suit, which was apparently foredoomed from the outset, may well have been brought in anticipation of an appeal to the United States Supreme Court. Had Wheeler challenged only the statute at issue in the initial Vermont decision, the Supreme Court might have dismissed the appeal without reaching the merits in light of the change in the Vermont law. As it turned out, of course, Wheeler gained little by his persistence. For present purposes there is no analytically relevant distinction between the two Wheeler cases. Therefore, in examining the issues there presented, references to the reasoning of both will be made interchangeably. However, in order to simplify the discussion, all subsequent references to the Vermont taxing provisions will be to the statutory scheme at issue in the second Wheeler decision, which is substantially the same as that in force today.

38. See P-H State and Locas Taxes (All States Unit) I 1002 (1974). The extent of federalization will vary from state to state. $I d$.

39. VT. STAT. ANN. tit. 32, $\$ 5822$ (1970). The "Vermont income" of a nonresident taxpayer consists of (1) rents and royalties derived from Vermont property, (2) gains from the sale or exchange of Vermont property, (3) wages, salaries, commissions or other income resulting from services performed in Vermont, and (4) income derived from a business, trade, occupation, or profession to the extent carried on in Vermont. VT. STAT. ANN. tit. 32, \& 5823(b) (Supp. 1973). Military pay for full-time active duty with the armed services and income exempted from state taxation under federal law are specifically excluded from the statutory definition of a nonresident's Vermont in. come. VT. Stat. ANN. tit. 32, § 5823(b) (Supp. 1973). "Adjusted gross income" is defined as "adjusted gross income ... determined under the laws of the United States." VT. STAT. ANN. tit. 32, § 5811(1) (1970). 
Wheeler's total 1968 earnings of $\$ 9,219$ produced a federal income tax bill of $\$ 1,413.33$. Twenty-five per cent of this liability amounted to $\$ 353.33$, and, reducing this figure by the percentage of his adjusted gross income that did not constitute Vermont income-seventy per cent-Wheeler would have owed a sum of $\$ 106$ to the Vermont tax authorities.

Although the statute unambiguously required a nonresident to compute his Vermont income tax liability pursuant to the method described above, Wheeler took a different approach. He began by ascertaining the portion of his income earned from his Vermont sales activities, which Vermont could unquestionably tax. This he determined to be $\$ 2,765.59$. After allowing for the statutory deductions and exemptions in the proportion that his Vermont-derived income bore to his total income, ${ }^{40}$ Wheeler arrived at a figure of $\$ 2,059$, which he denominated his "taxable Vermont income." Finally, turning to the Vermont taxing formula quoted above, ${ }^{\sharp 1}$ Wheeler applied the appropriate federal tax rate to his "taxable Vermont income" to produce a figure of $\$ 319$ and multiplied this by twenty-five per cent to ascertain a Vermont tax liability of $\$ 79.75 .{ }^{42}$

40. Wheeler's Vermont-derived earnings of $\$ 2,765.59$ constituted 30 per cent less $\$ .11)$ of his total earnings of $\$ 9,219$. He therefore concluded that he was entitled to 30 per cent of the deductions and exemptions allowed by the Vermont tax statute. Since, as noted above, the Vermont statute was simply derivative of the federal statute, Wheeler determined that he should be permitted to take 30 per cent of the 10 per cent standard deduction, INT. Rev. CoDz of 1954, ch. 1, § 141, 78 Stat. 23 (now INT. Rev. CODE OF 1954, \$141), and of the $\$ 600$ personal exemption (of which he was entitled to two). INT. Rev. CoDE of 1954, ch. 1, § 151, 68A Stat, 42 (now INT. REv. CoDE of $1954, \S 151)$.

Although the theory behind Wheeler's calculations is clear enough, the computations themselves are erroneous. The arithmetic, as set out by the court, $127 \mathrm{Vt}$. at 501, 253 A.2d at 138, shows the following:

Appellant's Vermont-Derived Income: $\quad \$ 2,766$

$30 \%$ of deductions: (\$921) $\quad 307$

\begin{tabular}{lr}
$30 \%$ of exemptions: $(\$ 1,200)$ & 400 \\
\hline & Taxable Vermont Income:
\end{tabular}

Apparently the distinction between one third and 30 per cent escaped Wheeler, who concluded that 30 per cent of $\$ 921$ equals $\$ 307$ and that 30 per cent of $\$ 1,200$ equals $\$ 400$; in fact, the respective dollar figures should have been $\$ 276.30$ and $\$ 360$.

41. See text accompanying note 39 supra.

42. The points of agreement and disagreement between Wheeler and Vermont may be more clearly illustrated in the following manner:

\begin{tabular}{|c|c|c|c|}
\hline \multicolumn{2}{|c|}{ Statutory Computation } & \multicolumn{2}{|c|}{ Wheeler's Computation } \\
\hline Total income: & $\overline{\$ 9,219.00}$ & Total income: & $\overrightarrow{\$ 9}, 219.00$ \\
\hline Vt. income: & $2,765.59$ & Vt. income: & $2,765.59$ \\
\hline Fed. tax liability & & Fed. tax lia- & \\
\hline $\begin{array}{l}\text { on taxable fed. } \\
\text { income: }\end{array}$ & $1,413.33$ & $\begin{array}{l}\text { bility on taxable } \\
\text { Vt. income: }\end{array}$ & 319.00 \\
\hline $\begin{array}{l}\text { Vt. measure of } \\
\operatorname{tax}(25 \%):\end{array}$ & 353.33 & $\begin{array}{l}\text { Vt. measure of } \\
\operatorname{tax}(25 \%):\end{array}$ & $\$ 79.75$ \\
\hline $\begin{array}{l}\text { Reduction to re- } \\
\text { flect percentage } \\
\text { of Vt. derived-income: }\end{array}$ & $30 \%$ & & - \\
\hline Vt. tax: & $\$ 106.00$ & Vt. tax: & $\$ 79.75$ \\
\hline
\end{tabular}


The basic issue that divided Wheeler and Vermont was thus clearly drawn: whether it is constitutionally permissible for a state to predicate the progressive rate at which a nonresident pays state income tax upon the nonresident's total income wherever earned.48 The different answers Wheeler and Vermont offered to this question did not stem from any disagreement over fundamentals. Neither sought to challenge the settled constitutional canons that states may tax nonresidents only on income earned within the state ${ }^{44}$ and that they must tax residents and nonresidents on a nondiscriminatory basis. ${ }^{45}$ The debate instead centered on whether Wheeler's out-ofstate income was in fact being taxed, in violation of the due process clause, and whether Wheeler was a victim of discriminatory treatment by the Vermont tax authorities, in violation of the privileges and immunities ${ }^{46}$ and equal protection clauses. The due process question was clearly the crucial one: Any claim of unconstitutional discrimination ultimately rested on the premise that a state could look only to in-state income in classifying nonresidents for rate purposes; hence, were it determined that a state was constitutionally uninhibited by jurisdictional principles from looking to nonresidents' extraterritorial income for rate purposes, any argument that the legislature lacked the discretion to consider such income in classifying nonresidents for rate purposes would be drained of force. ${ }^{47}$

It was accepted that the due process issue was one of extraterritoriality. Wheeler sought to demonstrate the extraterritorial nature of the levy by stressing that his Vermont tax bill was increased as a result of his non-Vermont earnings. ${ }^{48}$ This, he believed, inexorably led to the conclusion that Vermont was taxing his non-Vermont income in violation of the due process clause. Vermont, on the other hand, without suggesting that it had any right to tax a nonresident's non-Vermont income, rested its case on the fact that the rate, however determined, was applied only to Vermont-derived income.40

43. In the view of the parties, the issue was "Does the Constitution of the United States bar a State from imposing an effective graduated income tax on nonresidents which for the purpose of applying the effective graduated rates to which residents are subject takes into account the nonresident's total net income from all sources, and then reduces the tax by the ratio of in-state income to total income?" $127 \mathrm{Vt}$. at 501, 253 A.2d at 138 .

44. Shaffer v. Carter, 252 U.S. 37, 52-54 (1920).

45. Travis v. Yale \& Towne Mfg. Co., 252 U.S. 60 (1920).

46. U.S. CONST. art. IV, § 2.

47. See note 79 infra.

48. $127 \mathrm{Vt}$ at $364,249 \mathrm{A.2d}$ at 889 . This was true, of course, only to the extent that Wheeler's non-Vermont income placed him in a higher tax bracket than that in which he would have been if his Vermont income alone were considered.

49. The Vermont statute required the nonresident to determine his Vermont tax 
Confronted with two characterizations of the Vermont levy that were entirely consistent with one another except for the legal conclusion to which they led, the Vermont supreme court, without seriously analyzing the problem, simply adopted the latter characterization and announced: " $[\mathrm{I}] \mathrm{n}$ reality what is happening is that Vermont income is being taxed at an increased rate and nothing more." "50 The court's position was tenable in so far as it described a constitutionally permissible result: Both Maxwell v. Bugbee ${ }^{51}$ and Great Atlantic \& Pacific Tea Co. v. Grosjean ${ }^{52}$ had dismissed due process objections to the inclusion of nontaxable extraterritorial elements in the determination of the rate of a tax upon a subject within the taxing power of the state. ${ }^{53}$ And, in fairness to the court,

liability as if he were a resident and then to reduce this to a percentage reflecting that portion of his total income earned in Vermont. In his calculations, the nonresident thus would never actually apply the federal rate schedule to his Vermont-derived income. However, as the following illustration demonstrates, the result would be the same if he had directly applied the federal rate schedule to his Vermont-derived income at effective rates reflecting his total income:

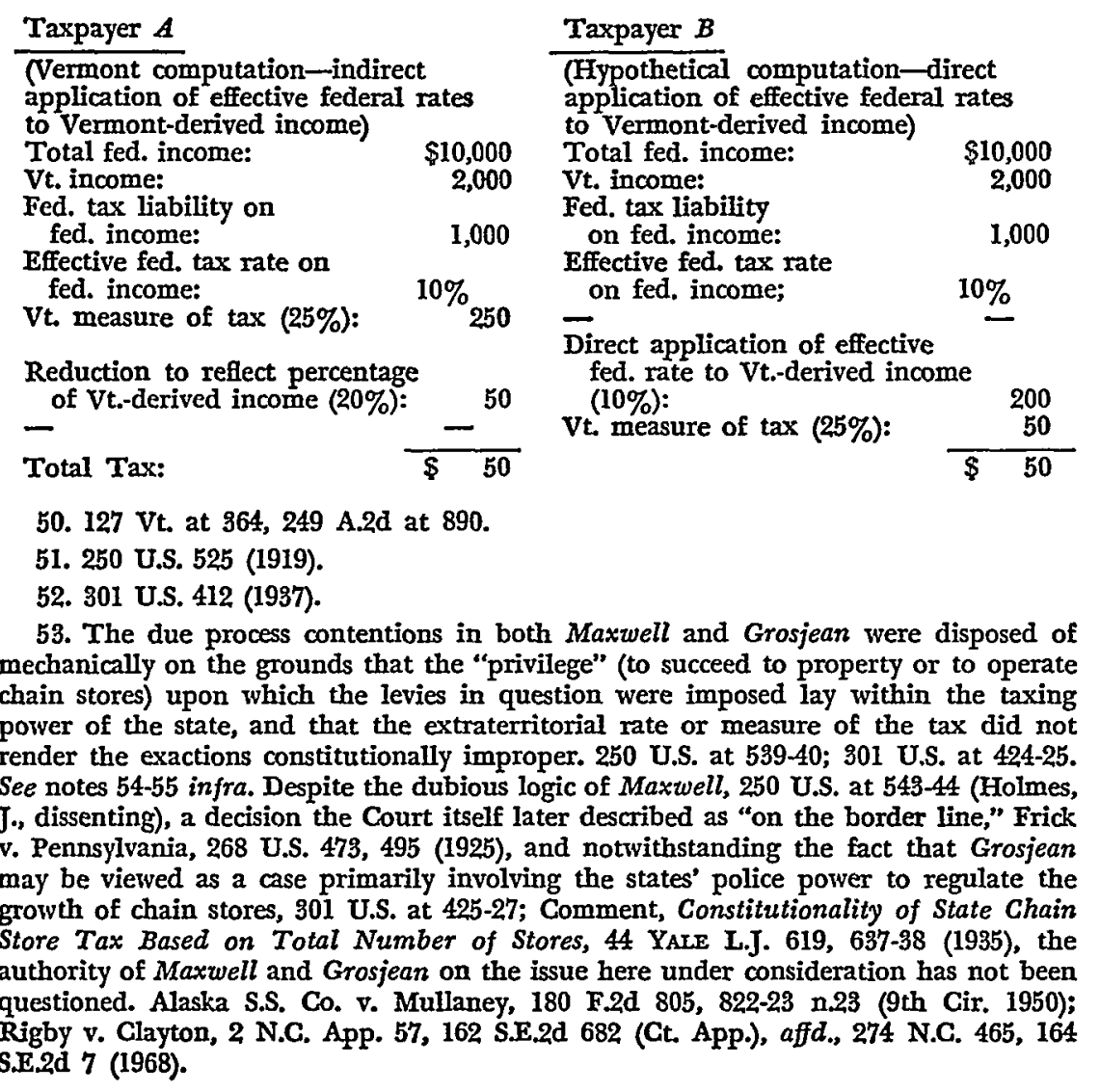


the grounds on which Wheeler and Vermont chose to do battle lay well within the accepted framework for examining due process attacks on state taxes. Nevertheless, the rhetoric of their debate, which the court's opinion perpetuated, failed to come to grips with the critical issue. By asking only whether in-state or out-of-state income was being taxed, neither the parties nor the court ever addressed the basic question whether the fundamental considerations underlying the limitations on a state's jurisdiction to tax a nonresident's income should be translated into corresponding limitations on a state's tax rate structure. Moreover, if one is to look beyond the distinctions between subject, measure, and rate, ${ }^{54}$ which, despite their constitutional significance, ${ }^{55}$ tend to confine analysis within artificial parameters, ${ }^{56}$ one must inquire on broader principles whether the overall taxpaying "ability" of the nonresident is a legitimate concern of the taxing jurisdiction in determining the individual's income tax bill.

We start with the notion, embodied in the concept of due process, that there is a distinction between the relationships of a resident and of a nonresident to the taxing power of a state. The distinction is rooted in the idea that the person who makes his home in a particular state both enjoys the general rights and owes the general obligations of citizenship in that jurisdiction, ${ }^{57}$ whereas the nonresident, who enters the state for a more limited purpose or for a shorter period of time, has a more narrowly defined relationship with that jurisdiction. ${ }^{58}$ This underlying difference finds concrete expression

54. The subject is the legal incidence of a tax. It is the thing or event upon which the power to tax is based; the measure of a tax is the yardstick to which the rate is applied. Subject and measure may be distinct, as in a privilege tax where the subject is the privilege and the measure is, for example, income; or subject and measure may coincide, as in an income tax where the income is both the subject upon which the tax power is predicated and the basis upon which the amount due is calculated.

55. It is well established that the subject of a tax must lie within a state's taxing power. Whether the measure of a taxable subject must also lie within the state's taxing power depends on the subject of the tax and the nature of the nontaxable value sought to be used as a measure. Compare Union Refrigerator Transit Co. v. Kentucky, 199 U.S. 194 (1905) with Southern Pac. Co. v. Kentucky, 222 U.S. 63 (1911); see Lowndes, supra note 7 , at $639-43$.

56. See Lowndes, supra note 7, at 639-49.

57. Miller Bros. v. Maryland, 347 U.S. 340, 345 (1954); Maguire v. Trefry, 253 U.S. 12, 17 (1920); Fidelity \& Columbia Trust Co. v. Louisville, 245 U.S. 54, 58 (1917); Kirtland v. Hotchkiss, 100 U.S. 491, 498-99 (1879).

58. Shaffer v. Carter, 252 U.S. 37, $52-53$ (1902); Goodwin v. State Tax Commn., 286 App. Div. 694, 701, 146 N.Y.S.2d 172, 180 (1955), affd. mem., I N.Y.2d 680, 150 N.Y.S.2d 203, 133 N.E.2d 711, appeal dismissed, 352 U.S. 805 (1956); Berry v. State Tax Commn., 241 Ore. 580, 583-84, 397 P.2d 780, 782 (1964), appeal dismissed, 382 U.S. 16 (1965). Writing in the late seventeenth century, Locke made essentially the same point: "But since the government has a direct jurisdiction only over the land, and reaches the 
in Supreme Court decisions reading the due process clause as permitting states to tax the entire income of their residents regardless of its source, ${ }^{59}$ while forbidding them to tax nonresidents on income derived from sources outside the state. ${ }^{60}$

But what is the theory of income tax jurisdiction that translates the distinction between resident and nonresident into a comparable distinction in the scope of state taxing power? To the extent that the states' jurisdiction to tax income rests on their "complete dominion over all persons, property, and business transactions within their borders," 11 it is not clear why the scope of their jurisdiction should be greater with respect to residents than nonresidents, since the existence of such "dominion" does not depend on whether it is a resident or nonresident who carries on an occupation, owns property, or engages in business transactions within the state. For the purpose of identifying the basis for the states' less extensive income tax jurisdiction over nonresidents than residents, it may therefore be more fruitful to examine the question in terms of the other fundamental predicate for state tax jurisdiction-the provision of benefits and protection to the taxpayer, his business, and his property.

The Supreme Court set forth its classic exposition of this principle in Wisconsin v. J. C. Penney Co.:82

A state is free to pursue its own fiscal policies, unembarrassed by the Constitution, if by the practical operation of a tax the state has exerted its power in relation to opportunities which it has given, to protection which it has afforded, to benefits which it has conferred by the fact of being an orderly, civilized society.

... [The] test is whether property was taken without due process of law, or, if paraphrase we must, whether the taxing power exerted by the state bears fiscal relation to protection, opportunities and benefits given by the state. The simple but controlling question is whether the state has given anything for which it can ask return. ${ }^{63}$

The Court's statement reflects the view that a state's tax jurisdiction

possessor of it (before he has actually incorporated himself in the society), only as he dwells upon, and enjoys that: the obligation any one is under, by virtue of such enjoyment to submit to the government, begins and ends with the enjoyment ...." J. LOCRE, SECONd Treatise of GOVERnMENT \& 121, at 62 (B. Blackwell ed. 1966). Of course, a nonresident's relationship to a taxing jurisdiction need not be based on physical presence; it may, for example, grow out of property he owns there.

59. See, e.g., Lawrence v. State Tax Commn., 286 U.S. 276 (1932).

60. See note 29 supra and accompanying text.

61. Shaffer v. Carter, 252 U.S. 37, 50 (1920); see also James v. Dravo Contracting Co., 302 U.S. 134, 138 (1937); Minnesota v. Karp, 84 Ohio App. 51, 53, 84 N.E.2d 76, 79 (1948).

62. 311 U.S. 435 (1940).

63. 311 U.S. at 444. 
bears a rough relationship to the benefits it provides the taxpayer, and countless decisions of both the Supreme Court and other tribunals have expressed similar sentiments. ${ }^{64}$ It is within this conceptual framework that the distinction between the state's jurisdiction to tax the income of residents and nonresidents becomes intelligible. Once one accepts the premise that there is a correlation between a state's right to tax and the opportunities it has given, the protections it has afforded, and the benefits it has conferred, it is not unreasonable to conclude that the scope of the state's income tax jurisdiction over residents and nonresidents should be different. The justification for allowing the states to tax residents on income earned from all sources is "founded upon the protection afforded to the recipient of the income by the state, in his person, on his right to receive the income, and in his enjoyment of it when received," "[e]njoyment of the privileges of residence in the state and the attendant right to invoke the protection of its laws . . . "Bo By the same token, however, since the nonresident receives neither the protection of the state in the enjoyment of his income nor other benefits of residence, ${ }^{67}$ except to the extent that he carries on an occupation, transacts business, or owns property in the state, the benefit rationale confines the state's income tax jurisdiction to "incomes accruing to non-residents from their property or business within the State, or their occupations carried on therein ...."'s8

64. See, e.g., Ott v. Mississippi Valley Barge Line Co., 336 U.S. 169, 174 (1949); Johnson v. Collector of Revenue, 246 La. 540, 573-74, 165 S.2d 466, 477-78 (1964); Morse v. Johnson, 282 A.2d 597, 600 (Me. 1971). As the Supreme Court has said: "The power of taxation, indispensable to the existence of every civilized government, is exercised upon the assumption of an equivalent rendered to the taxpayer in the protection of his person and property, or in the creation and maintenance of public conveniences in which he shares, such, for instance, as roads, bridges, sidewalks, pavements, and schools for the education of his children. Union Refrigerator Transit Co. v. Kentucky, 199 U.S. 194, 202 (1905). In Kiker v. Philadelphia, 346 Pa. 624, 631-32, 31 A.2d 289, 294 (1943), the Pennsylvania supreme court stated in connection with a challenge by a New Jersey resident to the imposition upon him of Philadelphia's income tax: "It is clear that in classifying persons for taxation an obligation on the part of the taxing power to make available some benefit to them must exist."

65. Lawrence v. State Tax Commn., 286 U.S. 276, 281 (1932).

66. New York ex rel. Cohn v. Graves, 300 U.S. 308, 313 (1937).

67. Nonresidents have attempted to quantify the benefits denied them as nonresidents in an effort to demonstrate that state income tax laws are unconstitutional insofar as the state levies taxes without providing benefits equivalent to those enjoyed by residents. For example, in American Commuters Assn. v. Levitt, 279 F. Supp. 40 (S.D.N.Y. 1967), affd., 405 F.2d 1148 (2d Cir. 1969), the plaintiffs unsuccessfully contended that the state and city of New York denied them 75.92 per cent of the benefits provided residents, including availability of welfare, education, and housing benefits, $279 \mathrm{~F}$. Supp. at 44. See also Stephan v. State Tax Commr., - Del. -, 245 A.2d 552 (1968), cert. denied, 394 U.S. 573 (1969).

68. Shaffer v. Carter, 252 U.S. 37, 52 (1920). In an attempt to develop a jurisdictional 
Whether the jurisdictional relationship between the nonresident taxpayer and the taxing state is conceived in terms of the dominion the state exercises over the nonresident's income-producing activities or the benefit and protection the state provides with respect to those activities, one must conclude that the application of progressive rates to the nonresident on the basis of his income from all sources imports into the taxing state's rate structure factors lying outside the scope of such relationship. However, this conclusion does not end the present inquiry. For, even if it raises some doubts about the defensibility of the results in Maxwell and Grosjean, other questions remain. For one thing, while paying lip service to the proposition that a state may not tax a nonresident or foreign corporation on income arising from out-of-state activities, the Court, with rare exceptions, ${ }^{69}$ has sustained state statutes that tax the net income of a foreign corporation by means of formulas under which a corporation's entire net income, wherever earned, is taken into account and is then apportioned to the state by reference to the ratio of in-state property, payroll, and the like to the total wherever owned, employed, or expended. ${ }^{70}$ Such formulas have been sustained even though they may constitute a transparent attempt by a state to maximize its revenues by distorting the income that is fairly attributable to activities carried on within its borders. ${ }^{71}$ Also, notwithstanding

construct consistent with the differing theories underlying the states' power to tax the income of residents and nonresidents, one student of the field has suggested that the personal income tax should be considered a dual tax for jurisdictional purposes-a personal tax levied upon all the income of residents and a tax upon income created within a state's borders regardless of the residence of the recipient. Fisher, Toward a Theory of Personal Income Tax Jurisdiction, 33 TAXEs 373 (1955). Fisher would substitute for the existing system, which he argues erroneously assumes that the income tax is a "single tax with two bases of jurisdiction," id. at 380 (see Chestnut Sec. Co. v. Oklahoma Tax Commn., 125 F.2d 571, 575 (10th Cir.), cert. denied, 316 U.S. 668 (1942)), a system wherein states would levy two separate taxes-one based on residence and the other on situs. Fisher, supra, at 380 . While Fisher's proposal is conceptually attractive in terms of his notion of jurisdictional neutrality, the state legislatures have shown no inclination to move in that direction, despite the warning that "if the states do not put their own house in order, somebody else eventually will do it for them." Groves \&: Fisher, State Multiple Taxation of Personal Income Re-examined, 33 TAXES 36, 40 (1955). (1931).

69. E.g., Hans Rees' Sons, Inc. v. North Carolina ex rel. Maxwell, 283 U.S. 123

70. Butler Bros. v. McColgan, 315 U.S. 501 (1942); Underwood Typewriter Co. v. Chamberlain, 254 U.S. 113 (1920). In Butler Bros. and Underwood Typewriter the Court rejected the contention that the due process clause was violated, despite the taxpayer's claim in the former that "the formula taxed extraterritorial valties," 315 U.S. at 510, and in the latter that the tax "directly or indirectly ... is imposed on income arising from business conducted beyond the boundaries of the State." 254 U.S. at 120.

71. Maxwell v. Kent-Coffey Mfg. Co., 204 N.C. 365, 168 S.E. 397, affd. mem., 291 U.S. 642 (1933), represents an extreme example of this tendency. The Court there sustained a 
the continued vitality of the generalization that the contours of the relationship between the taxpayer and the taxing state are shaped by the benefits the latter provides the former, ${ }^{72}$ it is well established that the due process clause does not require that the taxpayer's tax liability reflect the benefits he actually receives. ${ }^{78}$ Above all, however, is the fact that the whole idea of a progressive rate structure predicated on ability to pay ${ }^{74}$ and the question of its proper application

North Carolina income tax that allocated 99 per cent of a corporation's tax base to a state by means of a single-factor property formula, although the taxpayer sold less than 1 per cent of its products in the state. See generally Comment, State Taxation of Interstate Commerce: Roadway Express, the Diminishing Privilege Tax Immunily, and the Movement Toward Uniformity in Apportionment, 36 U. CHI. L. REv. 186, 207-18 (1968).

72. See, e.g., Evansville-Vanderburgh Airport Authority Dist. v. Delta Airlines, Inc., 405 U.S. 707, 712 n.5 (1972); Norfolk \& W. R.R. v. Missouri State Tax Commn., 390 U.S. 317, 325 n.5 (1968).

73. See, e.g., Stephen v. State Tax Commr., - Del. -, 245 A.2d 552 (1968), cert. denied, 394 U.S. 573 (1969). In Stephan, the taxpayers, nonresidents of Delaware, sought to reduce their Delaware tax liability to 25.2 per cent of the amount otherwise due on the ground that, as nonresidents, they were ineligible to receive certain benefits available to Delaware residents. Claiming that their taxes should be reduced in proportion to their ineligibility for such benefits, they asserted that any other application of the Delaware income tax law with respect to them would be unconstitutional. The Delaware supreme court, after adverting to the statement quoted above (see text accompanying note 63 supra) from Wisconsin v. J.C. Penney Co., 311 U.S. 435,444 (1940), upon which plaintiffs had relied, concluded that "[t]he general principles there expressed are unquestionable; but in their application they cannot mean that the Fourteenth Amendment requires such individual tailoring of tax bill to benefits derived . . ." 245 A.2d at 555. See also Carmichael v. Southern Coal \& Coke Co., 301 U.S. 495, 521-25 (1937); Southern Pac. Co. v. Kentucky, 222 U.S. 63, 76 (1911); American Commuters Assn. v. Levitt, 405 F.2d 1148, 1152-53 (2d Cir. 1969).

74. It is important to point out that the phrase "ability to pay" is used here and throughout this article solely to identify the rationale that is most frequently invoked by courts, see, e.g., Knowlton v. Moore, 178 U.S. 41 , 109 (1900), commentators, see, e.g., Vickrey, The Problem of Progression, 20 FLA. L. REv. 437 (1968), and even legislatures, see, e.g., VT. STat. ANN. tit. 32, $\$ 5820(\mathrm{~b})(1970)$, to justify a progressive rate structure. Nevertheless, as Blum and Kalven make clear, W. BLUM \& $H$. KnLven, The UNEAsY CASE For Progressive TAXation (1953), while "ability to pay does furnish a slogan with emotive appeal to which almost everyone can subscribe. The difficulty, of course, is that the key phrase is so ambiguous that the slogan lacks any content." Id. at 64. This article, however, is concerned not with whether there exists a reasoned defense for the ability principle as the basis for a progressive tax structure or indeed whether there is any firm philosophical underpinning at all for such a rate structure. Rather the focus is the operation of a state's progressive rate structure as applied to nonresidents-whatever its rationale. Thus, the phrase "ability to pay" connotes here simply the generally accepted rationale for progressivity; its use is not designed either to suggest a preference for that rationale over others or to suggest that progressivity is defensible except on purely redistributive grounds.

The term "benefit" is used in the text with reference to the jurisdictional relationship between the taxpayer and the taxing state, whereas Blum and Kalven use the same term to describe one of the theoretical justifications for a progressive tax system. See id. at 35-39. As used in this article, the notion of benefit as a basis for taxation is meant only to connote the idea that taxes are thought loosely to represent the prices one pays for the services rendered by government, cf. Guterman, supra note 7 , at $1250-51$; Blum and Kalven, by contrast, use the term more specifically with 
to nonresidents involve issues that lie entirely outside the conceptual universe of dominion and benefit. While the dominion and benefit rationales relate to the jurisdictionally appropriate scope of the relationship between the taxpayer and the state, the rationales for progressivity relate principally to the relationship of some taxpayers to other taxpayers. ${ }^{75}$

The determination that a taxpayer shall shoulder a proportionately greater tax burden as his income rises represents a basic political judgment about the manner in which the costs of government are to be shared. It seeks to distinguish taxpayers with reference to how much they earn and demands increasing portions of their income on the basis of that distinction. This is not a determination that has any necessary relationship to political boundaries. If a state resolves that it is appropriate for an individual who earns $\$ 100,000$ to pay at the rate of $\$ .25$ on the dollar, it would appear to make no difference in terms of that determination whether the individual accumulated the sum by earning $\$ 100,000$ in one state or $\$ 2,000$ in fifty states. The argument for permitting a state to look to a taxpayer's total income from all sources for purposes of its progressive rate structure would therefore seem to be a logical corollary of the rationale for such a rate structure, a rationale that has essentially nothing to do with the territorial limits of the taxing state.

reference to the theory that the benefits one receives from government increase as income increases-and perhaps even more rapidly than income, in which event a progressive tax would be theoretically justified. W. BLuM \& H. KalvEN, supra, at 35-39; see Magotin v. Illinois Trust \& Sav. Bank, 170 U.S. 283, 300 (1898).

75. One might argue that this contrast oversimplifies the problem. W. BLUM \& H. KaLven, supra note 74 , at 58 , consider a number of theoretical rationales for progressivity, not all of which can be characterized as involving solely the relationship between one taxpayer and another rather than that between a taxpayer and the taxing jurisdiction. Progressivity has been justified on the grounds that it contributes to the maintenance of a high and stable level of economic activity, id. at 29-35; that it allocates the tax burden according to the benefits received from the government, id. at 35-39; that it equitably apportions among taxpayers the sacrifice that the payment of a tax entails, $i d$. at $39-47$; that it produces the minimum aggregate sacrifice (or the greatest good for the greatest number), id. at 49-55; that it distributes the tax burden in accordance with ability to pay, $i d$. at $64-68$; and that it mitigates economic inequality through an effective redistribution of income. Id. at 70-80. Nevertheless, it seems fair to say that the most compelling justifications for progressivity, and those most widely perceived to form the basis for it, relate essentially to fairness among taxpayers-that is, how the tax burden is to be shared-rather than to the jurisdictional relationship between taxpayer and taxing jurisdiction. Whether these rationales are couched in terms of "ability to pay," "equal sacrifice," or "income redistribution," they all signify a judgment that the fiscal obligations of the taxpayer depend on his position in relationship to other taxpayers-whether he has the same taxpaying ability as others, whether he is being asked to sacrifice the same as others, whether he should be made economically more equal to others; they do not bear on whether his relationship to the state justifies the exaction. 
Since the justification for a progressive rate structure is rooted in fundamentally jurisdictionless concepts regarding the appropriate distribution of the tax burden, one confronts an analytic impasse. If the determination by a taxing state that different taxpayers with different incomes should pay taxes at different rates is a value judgment that does not depend on the source of the taxpayer's income, it makes no sense, at least insofar as that value judgment is concerned, to inquire into the jurisdictional nexus between the taxing state and the taxpayer's income. By a parity of reasoning, if a state's right to tax a nonresident is roughly delimited by the notion of territorial dominion or quid pro quo, it is difficult rationally to defend a tax that is determined in part by factors outside the critical jurisdictional relationship.

The clash of concepts is unavoidable ${ }^{76}$ and one must face the central question head on: If a state has no business increasing a nonresident's tax bill by taxing income the nonresident earns elsewhere, what business does it have increasing that bill by considering such income in its rate structure? The honest answer seems to be that the outcome is doctrinally impure; the conflict is not more apparent than real. There is a "logical antagonism"7r between the principles of dominion and benefit underlying a state's power to tax the income of nonresidents and the principles underlying a progressive tax rate structure predicated on ability to pay. In short, the result in Wheeler is an untidy compromise.

Perhaps it is possible to make intellectual peace with the inter-

76. This is not to suggest that the two theories of taxation necessarily work at cross-purposes. In Shaffer v. Carter, 252 U.S. 37 (1920), a progressive income tax was levied on a nonresident by the state of Oklahoma. However, only Oldahoma-earned income was considered in determining the nonresident's tax rate. The Court could thus unabashedly speak of "dominion," "benefit," and "ability to pay" in the same breath:

In our system of government the states have general dominion, and, saving as restricted by particular provisions of the Federal Constitution, complete dominion over all persons, property, and business transactions within their borders; they assume and perform the duty of preserving and protecting all such persons, property, and business, and, in consequence, have the power normally pertaining to governments to resort to all reasonable forms of taxation in order to defray the governmental expenses .....

Income taxes are a recognized method of distributing the burdens of government, favored because requiring contributions from those who realize current pecuniary benefits under the protection of the government, and because the tax may be readily proportioned to their ability to pay.

252 U.S. at 50-51. Not until the taxing jurisdiction attempts to look beyond the nonresident's in-state earnings to determine his tax rate does the latent conflict between the principles of dominion or benefit and ability to pay become apparent.

77. See Lowndes, supra note 4 , at 768. 
section of these conflicting theories of taxation by acknowledging the conflict and learning to live with it. It may be difficult to dismiss a lurking sense of discomfort when one contemplates that it is on the basis of what a New Hampshireman does in New Hampshire that his Vermont tax increases. Perhaps the discomfort stems from the idea that Vermont ought not be permitted to discourage, albeit weakly, a New Hampshireman's income-producing activity in New Hampshire by increasing his Vermont tax bill as a result thereof. ${ }^{78}$ In the final analysis, however, the progressive principle proves at least as compelling. We cannot rationally and fairly implement the concept that those who earn more should pay taxes at an increasingly higher rate unless we determine how much an individual earns without regard to the particular political entity or entities in which his earnings are accumulated. In sum, like the case for progression itself, the argument for freeing a progressive rate structure from jurisdictional restraints associated with state taxing power appears to be "stubborn but uneasy."79

\section{The Vermont Scheme-II}

Progressive taxation, however alluring philosophically, may become politically inexpedient at high rate levels. Perhaps for this reason, the Vermont legislature, despite its declaration that the

78. Of course, the empirical foundation for such an idea is at best problematic, for it has never been demonstrated that tax disincentives, especially at such low marginal rates as Vermont's statute imposes, discourage income-producing activity. See $\mathbf{O}$. Ecrstein, Public Finance $73-75$ (1964); Break, Income Taxes and Incentives To Work: An Empirical Study, $47^{\circ}$ AM. ECoN. REv. 529 (1957).

79. W. BLUM \& H. KALVEN, supra note 74, at 103.

In addition to his due process claims, Wheeler contended that the Vermont levy discriminated against nonresidents in violation of the equal protection clause and article IV's privileges and immunities clause. Once the jurisdictional objections to the consideration of nontaxable income for rate purposes are disposed of, however, any suggestion that a classification based on consideration of such income is unconstitutionally discriminatory borders on the frivolous. An assertion of irrational and arbitrary classification against nonresidents in violation of the equal protection clause has substance only if one characterizes the classification scheme as Wheeler did. He would have compared himself with the class of resident taxpayers all of whose income was earned in Vermont in an amount equal to what he had earned there and concluded that the higher rate at which his Vermont income was being taxed constituted arbitrary and unreasonable discrimination against outsiders. Inasmuch as Vermont was under no constitutional constraint to adopt Wheeler's comparative criteria, and, indeed, for reasons discussed above, could legitimately reject such a comparison in favor of one comparing taxpayers having the same total income wherever earned, the equal protection and privileges and immunities clauses were not violated. See, e.g., Mullaney v. Anderson, 342 U.S. 415 (1952); Wheeling Steel Corp. v. Glander, 337 U.S. 562, 572-74 (1949). See also Lucas, Constitutional Law and Economic Liberty, 11 J. LAw \& ECON. 5, 28-29 (1968). 
Vermont income tax was intended to "reflect the taxpayer's ability to pay as measured by his adjusted gross income for the taxable year," 80 felt constrained to soften the impact of its graduated rate structure. It did so by providing that a taxpayer's "net" Vermont income tax liability ${ }^{81}$ should not under any circumstances exceed 4.5 per cent of his "total income."82 If the computed tax exceeds the statutory ceiling, the taxpayer's bill is reduced by the amount of the excess. While Vermont may thus be accused of abandoning the theoretical basis of its income tax system by undermining its progressive rate structure, in terms of dollars and cents the statutory ceiling offered cold comfort to those who saw in it a relief from the burden of progressivity. The measure did, however, set the stage for a serious constitutional challenge.

By limiting one's "net" Vermont income tax liability to 4.5 per cent of one's "total income," the Vermont legislature engrafted a mechanism for achieving a proportional contribution from its taxpayers upon a system designed to achieve a progressive contribution. A proportional rate structure reflects the belief that individuals contribute their fair share to the costs of government when each pays an equal share of his income to defray those costs. In contrast, a progressive system reflects the belief that it is appropriate for those with greater incomes to pay greater shares of their income to defray such costs. The two theories may peacefully coexist in the same tax system so long as they operate at different rate levels or on different categories of income. In the federal system, for example, the rate structure on ordinary income is progressive up to the rate of seventy per cent, at which point it becomes proportional, and for certain taxpayers the rate on capital gains is entirely proportional. ${ }^{88}$

80. VT. StaT. ANN. tit. $32, \S 5820(\mathrm{~b})$ (1970).

81. His estimated Vermont tax liability less the federal tax savings resulting from Vermont taxes paid. VT. STAT. ANN. tit. 32, \& 5828(a) (1970).

82. Maximum tax liability.-(a) Notwithstanding any other provision of this chapter to the contrary, the Vermont income tax of an individual for any taxable year shall not in any case equal an amount such that the combined Vermont and federal income tax liability of the taxpayer for that taxable year, less the federal income tax liability (without consideration of the deduction for Vermont income taxes paid or accrued) of the taxpayer for that taxable year exceeds $41 / 2$ percent of the total income of the taxpayer for that taxable year.

(b) For purposes of this section, the "total income" of any individual for any taxable year means the sum of:

(1) the adjusted gross income,

(2) any amount of capital gains excluded from adjusted gross income, and

(3) interest on obligations of any state, municipality or the United States, of the taxpayer for that taxable year.

VT. STAT. ANN. tit. 32, $\$ 5828$ (1970).

83. INT. REV. CODE OF 1954, §§ 1, 1201(b). 
The underlying conflict surfaces only when there is an overlapping of rate structures. This is precisely what happens under Vermont's tax scheme, although generally at income levels that make the problem academic for most taxpayers. ${ }^{84}$ At the point that a taxpayer's "net" Vermont tax liability"s reaches 4.5 per cent of his "total income," $" 80$ his Vermont tax bill begins to increase on a proportional rather than a progressive basis. ${ }^{87}$ While the arithmetic involved in determining the precise effect of the statutory ceiling requires a number of separate computations ${ }^{88}$ and varies with the particular circumstances of each taxpayer, the basic operation and impact of the formula may be simply illustrated..$^{89}$ Its effect on the nonresident

84. Although variations among individual taxpayers with respect to deductions, exemptions, and the like make it impossible to indicate a precise income level at which the Vermont limitation begins to operate, "[i]t is unlikely that the provision will benefit most taxpayers." Instructions to Vermont Form 103A "Special Tax Limitation Schedule"). Since the ceiling only operates if a taxpayer's net Vermont tax liability (which may be substantially less than his actual Vermont tax liability) exceeds 4.5 per cent of his total income (which may substantially exceed his taxable income), it is highly improbable that the ceiling would have any impact on taxpayers with less than $\$ 25,000$ total income. At such an income level, and without any unusual deductions or consideration of the distinction between actual and net Vermont tax liability, a married taxpayer would be paying an effective federal rate of about 19 per cent of his total income for calendar year 1973; and his Vermont tax liability would be 28 per cent of that figure, see Vr. STAT. ANN. tit. 32, $\$ \$ 5822$ (1970), 5830 (Supp. 1973), or 5.3 per cent of his total income.

85. See note 81 supra.

86. His federal adjusted gross income plus certain capital gains and tax-free income. VT. Stat. ANN. tit. 32, § 5828(b) (1970).

87. See note 89 infra.

88. Vermont Form 103A ("Special Tax Limitation Schedule") must be completed by taxpayers entitled to and desiring to take advantage of the 4.5 per cent limitation. One must make 19 entries and, under some circumstances, more than 10 separate calculations to complete the form.

89. Assume a Vermont resident with a total 1973 income of $\$ 100,000$ and taxable income of $\$ 76,000$. His federal tax liability would amount to $\$ 31,020$ and his Vermont tax liability, before taking account of the statutory ceiling, to 28 per cent of this figure, or $\$ 8,685.60$. VT. STAT. ANN. tit. 32, $\$ \$ 5822$ (1970), 5830 (Supp. 1973). Assume further that our hypothetical taxpayer took a deduction of $\$ 6,000$ for taxes paid to Vermont during calendar year 1973. INT. REv. CoDE of 1954, § 164. In substance, he must subtract the tax benefit of this deduction at his highest marginal rate, that is, 58 per cent of $\$ 6,000(\$ 3,480)$, from his Vermont tax liability to determine his net Vermont tax liability of $\$ 5,205.60$ ( $\$ 8,685.60$ less $\$ 3,480)$. VT. STAT. ANN. tit. $32, \S 5820$ (b) (1970). Then, applying the 4.5 per cent ceiling $(\$ 4,500$ on a total income of $\$ 100,000)$, the taxpayer determines that his net Vermont tax exceeds the limitation by $\$ 705.60$, which he may subtract from his Vermont tax of $\$ 8,685.60$ for a total tax bill of $\$ 7,980$.

The following table illustrates the operation of Vermont's proportional limitation by a comparison (using 1973 federal and state rates) of the taxpayer described above with another who has earned an additional $\$ 1,000$ of total and taxable income, all other things being equal: 
taxpayer, however, created a problem that was not academic, and an illustration that was hardly hypothetical. ${ }^{.0}$

Like their fellow New Hampshireman Wheeler, Myron and Pearl Landgraf earned a portion of their income in Vermont. Unlike

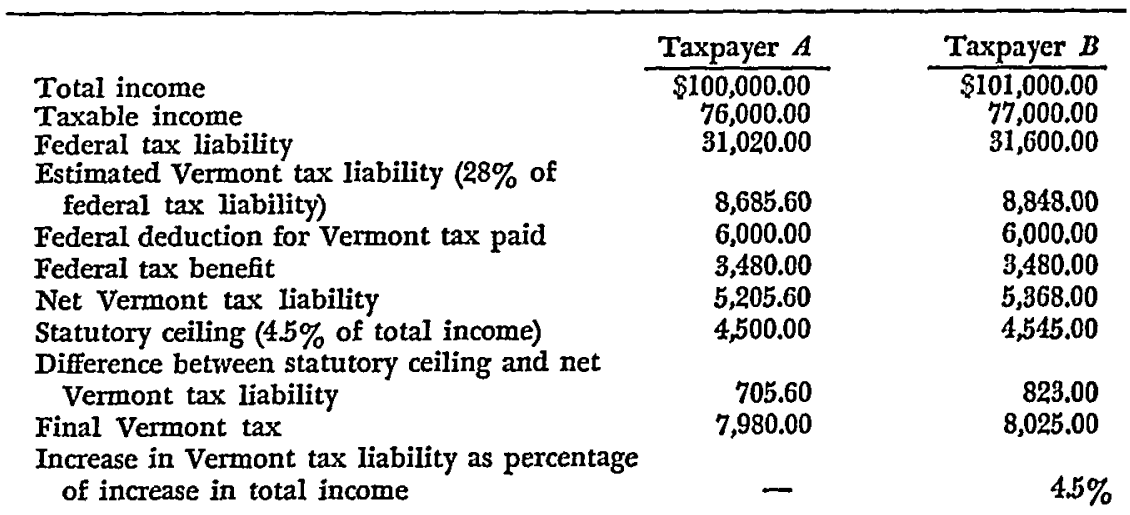

One additional point is relevant. Because the statutory ceiling applies to the net Vermont tax liability, one's final Vermont tax bill depends in part on the federal deduction for Vermont taxes paid. As the following table demonstrates, however, even though one's final Vermont tax bill will vary depending on the federal deduction for Vermont taxes paid, this will not affect one's total tax bill (Vermont plus federal) if the statutory ceiling applies. The table also demonstrates that when the statutory ceiling does not apply (as in the case of taxpayer $A$ ), the combined state and federal tax bill may be slightly lower than that of a taxpayer in an identical tax situation except for the amount of state taxes paid during the calendar year. The taxpayers in the table differ only in the amount of their federal deduction for Vermont taxes paid, which directly yields differences in their federal taxable income.

\begin{tabular}{|c|c|c|c|c|c|}
\hline & $\underset{A}{\text { Taxpayer }}$ & $\underset{B}{\text { Taxpayer }}$ & $\begin{array}{l}\text { Taxpayer } \\
\text { C }\end{array}$ & $\begin{array}{c}\text { Taxpayer } \\
D\end{array}$ & $\underset{E}{\text { Taxpayer }}$ \\
\hline Total income & $\$ 100,000$ & $\$ 100,000$ & $\$ 100,000$ & $\$ 100,000$ & $\$ 100,000$ \\
\hline for Vt. taxes & 8000 & 7000 & 6000 & 5000 & 0 \\
\hline $\begin{array}{l}\text { paid } \\
\text { Taxable income }\end{array}$ & $\begin{array}{r}8,000 \\
74,000\end{array}$ & $\begin{array}{r}7,000 \\
75,000\end{array}$ & $\begin{array}{r}6,000 \\
76,000\end{array}$ & $\begin{array}{r}5,000 \\
77,000\end{array}$ & $\begin{array}{c}0 \\
82,000\end{array}$ \\
\hline Fed. tax liability & 29,970 & 30,470 & 31,020 & 31,600 & 94,500 \\
\hline $\begin{array}{l}\text { Estimated Vt. } \\
\text { tax liability } \\
\text { (28\% of fed. } \\
\text { tax liability) }\end{array}$ & 8.39160 & 8.53160 & 8.685 .60 & 8.848 .00 & 966000 \\
\hline Fed. tax benefit & & & & & \\
\hline $\begin{array}{l}\text { for Vt. deduction } \\
\text { Net Vt, tax }\end{array}$ & $4,530.00$ & $4,030.00$ & $3,480.00$ & $2,900.00$ & 0 \\
\hline liability & $3,861.60$ & $4,501.60$ & $5,205.60$ & $5,948.00$ & $9,660.00$ \\
\hline Statutory & & & & & \\
\hline ceiling & $4,500.00$ & $4,500.00$ & $4,500.00$ & $4,500.00$ & $4,500.00$ \\
\hline Difference & 0 & 1.60 & 705.60 & $1,448.00$ & $5,160.00$ \\
\hline Final Vt. $\operatorname{tax}$ & $8,391.60$ & $8,530.00$ & $7,980.00$ & $7,400.00$ & $4,500.00$ \\
\hline Vt. ts & & & & & \\
\hline fed. $\operatorname{tax}$ & $\begin{array}{r}8,391.60 \\
29,970.00\end{array}$ & $\begin{array}{r}8,530.00 \\
30,470.00\end{array}$ & $\begin{array}{r}7,980.00 \\
31,020.00\end{array}$ & $\begin{array}{r}7,400.00 \\
31,600.00\end{array}$ & $\begin{array}{r}4,500.00 \\
34,500.00\end{array}$ \\
\hline & $38,361.60$ & $39,000.00$ & $39,000.00$ & $39,000,00$ & $39,000,00$ \\
\hline
\end{tabular}

90. Landgraf v. Commissioner, 130 Vt. 589, 298 A.2d 551 (1972). 
Wheeler, however, their income was substantial, and thus they faced the problem of how to construe the impact on a nonresident taxpayer of Vermont's 4.5 per cent ceiling. In 1969 the Landgrafs' "total income" was $\$ 76,886.52 .{ }^{21}$ As a result of various deductions, including one for Vermont income taxes paid, the Landgrafs' federal taxable income amounted to $\$ 69,456.85$ and their federal tax to $\$ 27,312.17$. A taxpayer's Vermont tax liability for 1969 (without consideration of the statutory limitation) was 28.75 per cent ${ }^{92}$ of his federal tax liability, which for the Landgrafs amounted to $\$ 7,852.24$. If under these circumstances the Landgrafs had been Vermont rather than New Hampshire residents, the Vermont statutory ceiling would have significantly reduced their Vermont tax liability; inasmuch as their "net" Vermont tax liability ${ }^{93}$ exceeded 4.5 per cent of their total income $(\$ 3,459.89)$ by $\$ 3,047.75$, they would have been entitled to reduce their Vermont tax as originally computed ${ }^{94}$ by this amount, to produce a final Vermont tax liability of $\$ 4,804.49$.

In their view, the Landgrafs could ascertain their Vermont tax liability simply by adjusting the above determined Vermont tax liability to reflect the portion of their total income earned in Vermont. In 1969 their Vermont-derived income was fifty-four per cent of their total income. Hence, they figured their Vermont tax liability to be fifty-four per cent of the Vermont tax liability of a Vermont resident with the same federal taxable income as theirs, and this came to $\$ 2,594.42 . .^{\circ 5}$ Indeed, this was precisely the method by which the Vermont tax commissioner determined the New Hampshire resident's Vermont tax liability in Wheeler. ${ }^{96}$

91. 130 Vt. at 591, $298 \mathrm{~A} .2 \mathrm{~d}$ at 553. For purposes of the textual discussion some of the arithmetical operations involved in making the statutory computations are collapsed or simplified and others are omitted if not germane to the analysis. The actual calculations made pursuant to Form 103A, see note 88 supra, by both the Landgrafs and the Vermont Commissioner of Taxes are set out in 130 Vt. at 592-94, 298 A.2d at 553-54.

92. As indicated above, see text accompanying note 39 supra, when Vermont introduced its federalized tax system, a taxpayer's Vermont tax liability was 25 per cent of his federal tax liability. In 1969, however, the Vermont legislature enacted a 15 per cent tax surcharge effective for taxable years beginning after December 31, 1968, which brought the effective Vermont rate to 28.75 per cent of one's federal tax liability. This rate applied to the Landgrafs in the tax year at issue. Vermont subsequently reduced the surcharge so that a taxpayer's effective Vermont tax rate is 28 per cent of his federal tax liability for 1973 and 27.25 per cent for later years. VT. SrAr. ANN. tit. 32, \& 5830 (Supp. 1973).

93. $\$ 6,507.64$, or their Vermont tax liability as originally computed $(\$ 7,852.24)$ less the federal tax savings resulting from their deduction for $\$ 2,246.37$ Vermont taxes paid $(\$ 1,344.60)$.

94. 28.75 per cent of the Landgrafs' federal tax liability, or $\$ 7,852.24$.

95. 54 per cent of $\$ 4,804.49$.

96. 127 Vt. at 363,249 A.2d at $889 ; 127$ Vt. at 501,253 A.2d at 138. 
Despite the logical basis of the Landgrafs' computations and their consistency with the principles approved in Wheeler, the operation of the statutory ceiling with respect to nonresidents compelled a different result. Because the provision stated that a taxpayer's net "Vermont income tax" should not exceed " $41 / 2$ per cent of the total income of the taxpayer for that taxable year," in the Landgrafs' position no benefit. In calculating the 4.5 per cent ceiling, a nonresident was required to look to his "total income" wherever eamed; but in determining whether the ceiling limited his Vermont tax bill, the nonresident was required to look to his actual "net" Vermont tax liability, which had been reduced to reflect only income earned in Vermont. The Landgrafs were consequently forced first to reduce the Vermont percentage ${ }^{98}$ of their federal tax liability by an additional 46 per cent to reflect the ratio of their nonVermont income to their Vermont income. As a result, the Landgrafs' "net" Vermont tax liability amounted to only $\$ 2,895.61$, , well below the statutory limitation of 4.5 per cent of their total income $(\$ 3,459.89)$. Since the limitation was not exceeded, the Landgrafs were liable for the full Vermont tax-as initially computed and appropriately adjusted to reflect solely their Vermont income-of $\$ 4,240.21$.

The unequal impact of Vermont's tax ceiling becomes clear when it is evaluated in terms of Vermont's constitutional power to tax the income of residents and nonresidents. In presenting the Landgrafs, only fifty-four per cent of whose total income was earned in and hence taxable by Vermont, a tax bill of $\$ 4,240.21$ while presenting a hypothetical Vermont resident with the same income, all of which is taxable by Vermont, a tax bill for $\$ 4,804.49$, Vermont has exacted a substantially larger portion of the nonresident's income than of the resident's income insofar as it may properly tax such income. Indeed, under Vermont's taxing scheme the Landgrafs pay roughly ten cents on every dollar taxable and taxed by Vermont, whereas their imag. ined counterparts would pay just six cents on every such dollar. ${ }^{100}$

\footnotetext{
97. VT. STAT. ANN. tit. 32 , § 5828(a) (1970). The provision is quoted in full at note 82 supra.

98. 28.75 per cent.

99. Their Vermont tax liability as originally computed $(\$ 4,240.21)$ less the federal tax savings resulting from their deduction for $\$ 2,246.37$ Vermont taxes paid $(\$ 1,344.60)$.

100. For the Landgrafs, the figure was calculated by determining the percentage that their final Vermont tax liability $(\$ 4,240.21)$ represented of their Vermont income ( $\$ 41,518.72$, or 54 per cent of their total statutory income of $\$ 76,886.52)$; for their Vermont counterparts, the figure was calculated by determining the percentage that their final Vermont tax liability $(\$ 4,804.49)$ represented of their total statutory income $(\$ 76,886.52)$. While it is arguably unrealistic to assume that a Vermont
} 
There can be no justification for such a disparity-at least in terms of the rationale that underlay Vermont's treatment of nonresidents with respect to her progressive rate structure. The basic proposition that legitimated Vermont's progressive rate structure as applied to nonresidents was that for rate purposes there should be no differentiation between residents and nonresidents who earn the same amount of money-regardless of where earned. The wandering minstrel who earned $\$ 2,000$ in fifty states would in principle pay to Vermont the same portion of his $\$ 2,000$ that an equally successful minstrel who never wandered outside Vermont would pay on his $\$ 100,000$, in contrast to the significantly lower portion (if any) that the nonresident would pay were he taxed as a Vermont resident whose income totaled $\$ 2,000$. This, of course, is what Wheeler was all about. Yet only a few years later, in Landgraf, the Vermont supreme court stood the rationale of Wheeler on its head by approving a statutory scheme that permitted Vermont to demand proportionally more of the constitutionally taxable income of a nonresident than of a resident.

and a non-Vermont taxpayer with the same total income would have identical deductions for Vermont taxes paid, as the Landgrafs assumed in comparing themselves with a hypothetical Vermont resident, the basic discrimination against the nonresident remains even if one compares a resident and nonresident whose federal deductions for Vermont taxes paid reflect the portion of their income taxable by Vermont. The following illustration (using 1973 rates) assumes the nonresident has earned 50 per cent of his income in Vermont; it also assumes that the resident and nonresident have equal taxable incomes, since it is on that basis that Vermont purports to treat all taxpayers equally for rate purposes:

\begin{tabular}{|c|c|c|}
\hline & Resident & Nonresident \\
\hline Total income & $\$ 100,000$ & $\$ 100,000$ \\
\hline \multicolumn{3}{|l|}{ Per cent taxable by } \\
\hline Vermont & $100 \%$ & $50 \%$ \\
\hline \multicolumn{3}{|l|}{ Fed. deduction for } \\
\hline Vt. taxes paid & 6,000 & 3,000 \\
\hline Taxable income & 76,000 & 76,000 \\
\hline Fed. tax liability & 31,020 & 31,020 \\
\hline \multicolumn{3}{|l|}{ Estimated Vt. tax } \\
\hline liability $(28 \%$ & & \\
\hline of fed. tax liab.) & $8,685.60$ & $8,685.60$ \\
\hline \multicolumn{3}{|l|}{ Adjustment for non- } \\
\hline resident & 一 & $\begin{array}{c}4,342.80 \\
(50 \% \text { of } 8,685.60)\end{array}$ \\
\hline \multicolumn{3}{|l|}{ Fed. tax benefit for } \\
\hline $\begin{array}{l}\text { Vt. deduction } \\
\text { Net Vt. tax liability }\end{array}$ & $3,480.00$ & $1,740.00$ \\
\hline Statutory ceiling & $4,500.00$ & $4,500.00$ \\
\hline Difference & 705.60 & 一 \\
\hline Final Vt. tax & $7,980.00$ & $4,342.80$ \\
\hline \multicolumn{3}{|l|}{$\begin{array}{l}\text { Final Vt. tax as } \\
\text { percentage of total } \\
\text { income taxable by }\end{array}$} \\
\hline Vermont & $7.98 \%$ & $8.69 \%$ \\
\hline
\end{tabular}


Landgraf was not one of the Vermont supreme court's happiest hours. Apparently lacking any firm analytical basis for upholding the levy, the court relied on bald conclusions:

Because appellants earn some $46 \%$ of their income from sources outside Vermont it is clearly erroneous for the appellants to compare themselves with a Vermont resident having the same federal taxable income as they do for the purpose of determining if the ceiling ... applies. Appellants have not made the showing of discrimination required by the doctrine set forth in Wheeler v. State . . . because they have not shown themselves to be disadvantaged when compared to another in an equivalent position. ${ }^{101}$

The court never suggested why the Landgrafs' comparison was "clearly erroneous," nor how it had determined the proper basis for comparison. In Wheeler, the court had reasoned that it was proper to compare residents and nonresidents with the same federal taxable income in determining whether residents and nonresidents were being accorded equal treatment with respect to the rate at which they paid taxes on their income taxable by Vermont. ${ }^{102}$ But the Landgraf court flatly refused to follow this rationale to its logical conclusion in applying the statutory ceiling. It failed to confront the fact that the statute introduced a bias against nonresidents with respect to the rate burden on income constitutionally taxable by Vermont. Instead it attempted to justify the result with the analytically irrelevant observation that "the New Hampshire taxpayer would never pay any greater tax than his Vermont counterpart."103

The constitutional questions raised by the operation of Vermont's statutory ceiling with respect to nonresidents are substantial. Both the privileges and immunities clause of article IV and the equal protection clause generally forbid states to discriminate against outsiders, in favor of locals. ${ }^{104}$ Admittedly, neither clause holds the states

101. $130 \mathrm{Vt}$. at $595-96,298 \mathrm{~A} .2 \mathrm{~d}$ at 555.

102. $127 \mathrm{Vt}$. at $366,249 \mathrm{~A} .2 \mathrm{~d}$ at 891.

103. $130 \mathrm{Vt}$. at 597, $298 \mathrm{~A} .2 \mathrm{~d}$ at 556.

104. See Mullaney v. Anderson, 342 U.S. 415 (1952); Toomer v. Witsell, 334 U.S. 385 (1948), with respect to the privileges and immunities clause, U.S. CoNsT. art. IV, \& 2; see WHYY, Inc. v. Glassboro, 393 U.S. 117 (1968); Wheeling Steel Corp. v. Glander, 337 U.S. 562 (1949), with respect to the equal protection clause. While the privileges and immunities clause speaks of the "citizens" of the states, the Supreme Court has stated that "a general taxing scheme $\ldots$ if it discriminates against all non-residents, has the necessary effect of including in the discrimination those who are citizens of other States." Travis v. Yale \& Towne Mfg. Co., 252 U.S. 60, 79 (1920). By contrast, however, the recent decision upholding New York's reduced stock transfer tax rate for nonresidents demonstrates that favoring outsiders over locals may not, in certain circumstances, be adjudged violative of either the privileges and immunities clause or the equal protection clause. Boston Stock Exch. v. State Tax Commn., - App. Div. 2d $\longrightarrow 357$ N.Y.S.2d 116 (1974). 
to an "iron rule of equality" 105 or condemns distinctions based on rational criteria. ${ }^{106}$ Yet somewhere the constitutional line must be drawn in a manner that allows the state to exercise its taxing power freely but not so freely that it is allowed to care for its own at the expense of others. According to Justice Frankfurter: "I think it is fair to summarize the decisions which have applied Art. IV, § 2, by saying that they bar a State from penalizing the citizens of other States by subjecting them to heavier taxation merely because they are such citizens or by discriminating against citizens of other States in the pursuit of ordinary livelihoods in competition with local citizens." 107 Essentially the same could be said with respect to the Court's decisions applying the equal protection clause to alleged tax discrimination between residents and nonresidents, ${ }^{108}$ although they are phrased in terms of a state's duty to "proceed upon a rational basis and . . . not resort to a classification that is palpably arbitrary."109

How does Vermont's taxing scheme stand up against these criteria? One could argue that Vermont's proportional tax ceiling neither singles out nonresidents for discriminatory treatment nor makes any arbitrary classification. The limitation is neutral on its face (4.5 per cent), has universal applicability (all taxpayers), and employs uniform standards (net Vermont tax liability and total income from all sources). Any unfairness resulting from the application of such a formula to nonresidents is thus arguably an "incidental" consequence of the implementation of a neutral principle, which is simply to say that all unfaimess is not unconstitutional.10 Furthermore, one could rely on the fact that the nonresident never actually pays any more Vermont tax than the resident, whether or not the nonresident pays at a higher rate. Hence, one might suggest that the nonresident's claim is at best an abstract complaint over how the Vermont levy should be conceptualized, that there is room for argument over its appropriate conceptualization, and that, since constitutional law is mired in conceptual quicksand anyway, the nonresident should not be entitled to relief unless he can show that he is demonstrably worse off than the resident..11

105. Allied Stores of Ohio, Inc. v. Bowers, 358 U.S. 522, 526 (1959).

106. General Am. Tank Car Corp. v. Day, 270 U.S. 367 (1926).

107. Toomer v. Witsell, 334 U.S. 385, 408 (1948) (concurring opinion).

108. E.g., Wheeling Steel Corp. v. Glander, 337 U.S. 562 (1949).

109. Allied Stores of Ohio, Inc. v. Bowers, 358 U.S. 522, 527 (1959).

110. As the Court stated in Salomon v. State Tax Commn., 278 U.S. 484, 491-92 (1929): "To all such objections it may be answered that minor inequalities and hardships are incidents of every system of taxation and do not render the legislation obnoxious to the Federal Constitution."

111. Such as were the nonresident commercial fishermen in Toomer v. Witsell, 334 
But these are feeble excuses in light of the purposes underlying Vermont's tax scheme. Vermont's basic tax structure was explicitly predicated on the idea that the resident and nonresident taxpayer with the same ability to pay ought to pay to Vermont the same percentage of their income taxable by Vermont. When Vermont imposed its proportional limitation it effectively destroyed this equality. While it is true that the maximum Vermont tax burden on either taxpayer is the same in absolute terms, the basis of the equality between them was never so conceived. The point is simply that Vermont should not be permitted to have it both ways. If it chooses to tax all taxpayers on the basis of the principle that those with the same ability to pay should pay taxes to Vermont at the same rate, it cannot in the next breath enact a statute that makes this principle "inoperative" with respect to high bracket taxpayers. If this is not a problem of constitutional significance, ${ }^{112}$ it is nevertheless an inequity inconsistent with the salutary principle that lay at the heart of the Vermont statute.

\section{Nonproliferation of Progressive Rates BASED ON INCOME WHEREVER EARNED}

"Is there any point to which you would wish to draw my attention?"

"To the curious incident of the dog in the night-time."

"The dog did nothing in the night-time."

"That was the curious incident," remarked Sherlock Holmes.113

It is indeed curious that more than fifty years after the Supreme Court put its imprimatur on a progressive state tax structure that assessed nonresidents at rates determined in part by nontaxables, ${ }^{114}$ only four jurisdictions ${ }^{116}$ have adopted such a rate structure for their personal income tax systems. It is curious first because such a taxing scheme is as politically painless a method of garnering additional revenue as state legislators are likely to find. Indeed, taxing states have repeatedly been compelled by courts to demand less from non-

U.S. 385 (1948), who were compelled to pay a license tax one hundred times as great as that imposed on residents.

112. But see Smith v. Loughman, 245 N.Y. 486, 490, 157 N.E. 753, 756, cert. denied, 275 U.S. 560 (1927); Goodwin v. State Tax Commn., 286 App. Div. 694, 702, 146 N.Y.S.2d 172, 181 (1955), affd. mem., 1 N.Y.2d 680, 150 N.Y.S.2d 203, 133 N.E.2d 711, appeal dis. missed, 352 U.S. 805 (1956) (state cannot discriminate against nonresident in terms of rate).

113. A. Doyze, Silver Blaze, The Memoirs of Sherlock Holmes (1894), in THE ComPLETE SHERLOCK HOLMES 347 (n.d.).

114. Maxwell v. Bugbee, 250 U.S. 525 (1919).

115. Mo. Rev. StAT. ANN. \& 143.041 (Supp. 1974); NEb. Rev. Stat. \& 77-2715 (Supp. 1973); R.I. GEN. LAws ANN. § 44-30-33 (Supp. 1973); VT. STAT. ANn. tit. 32, § 5822 (1970). For a discussion of the former practice of territorial Alaska see note 133 infra. 
residents than was their initial inclination, ${ }^{116}$ and here was presented a constitutionally sanctioned method by which to demand more. It is also curious because a number of states that have hesitated to enact income taxes with rate structures such as that in question have nevertheless enacted similar structures with respect to death taxes. ${ }^{117} \mathrm{Fi}$ nally, it is curious because it is frequently administratively as easy -and occasionally administratively easier-to calculate the nonresident's rate on the basis of his income wherever earned as on his income earned within the state. It is therefore appropriate to inquire why most states have refrained from adopting a formula such as Vermont's ${ }^{118}$ for their personal income tax.

Since there is no longer a serious question about the constitutional propriety of a progressive state tax structure that includes a nonresident's nontaxable out-of-state income in determining the rate at which he will pay, ${ }^{119}$ a state's choice of such a structure is fundamentally an issue of policy. To determine whether there are any substantial policy reasons for not adopting this approach to the taxation of nonresidents, it is first necessary to identify the policies underlying a state's existing tax system. Forty-four states and the District of Columbia impose a tax on personal income. ${ }^{120}$ Three states impose their tax only on residents and only on a limited category of income. ${ }^{121}$ Two states impose a so-called "commuter's tax,"122 an ingenious if constitutionally questionable ${ }^{123}$ scheme designed by

116. See, e.g., Toomer v. Witsell, 334 U.S. 385 (1948); Travis v. Yale \& Towne Mfg. Co., 252 U.S. 60 (1920); Ward v. Maryland, 79 U.S. (12 Wall.) 418 (1870).

117. See note 137 infra.

118. The reference, of course, is only to the basic Vermont taxing scheme discussed in Part II supra; it is not intended to include the wrinkle added by Vermont's proportional ceiling discussed in Part III supra.

119. See Alaska S.S. Co. v. Mullaney, 180 F.2d $805,822-23$ n.23 (9th Cir. 1950); Wheeler v. State, 127 Vt. 361, 249 A.2d 887, appeal dismissed, 396 U.S. 4 (1969). Cf. Great Atl. \& Pac. Tea Co. v. Grosjean, 301 U.S. 412 (1937); Maxwell v. Bugbee, 250 U.S. 525 (1919); Rigby v. Clayton, 2 N.C. App. 57, 162 S.E.2d 682, affd., 274 N.C. 465, 164 S.E.2d 7 (1968). See generally Part II supra.

120. Only Florida, Nevada, South Dakota, Texas, Washington, and Wyoming impose no personal income taxes. 1 P-H State and Local TAxes (All States Unit) If 101, at 104 (1974).

121. New Hampshire and Tennessee impose a tax on intangibles. N.H. REv. STAT. ANN. \$§ 77:1-17, :17-a, :18-23, :27-29, :30-a-36 (1970), :24-25-a, :30 (Supp. 1973); TENN. CODE ANN. \$§ 67-2603-06, -2608, -2610-12, -2615-17 (1955), -2601-02, -2607, -2609, -2613-14, -2618-35 (Supp. 1973). Connecticut imposes a tax on capital gains. ConN. GEN. StAT. ANN. \$\$ 12-506a-07, -509-22 (1958), -505-06, -508 (Supp. 1973).

122. N.H. Rev. StAT. ANN. \$§ 77-B:2-3, :5-21,:24-28 (1970), :1, :4,:22-23 (Supp. 1973); N.J. Rev. STAT. ANN. \$§ 54:8A-1-118 (Supp. 1973).

123. See J. HinLlersteIN, supra note 11, at 614; but see Austin v. State Tax Commn., - N.H. -, 316 A.2d 165, prob. juris. noted, 43 U.S.L.W. 3208 (U.S. Oct. 15, 1974) (upholding constitutionality of New Hampshire's commuter's tax). 
states without general income taxes of their own. The states increase their revenues through a "sponge" tax that, by effectively taxing only nonresidents who work in the state, absorbs the income tax credits allowed by neighboring states for taxes paid to "other" states.124 Of the remaining forty-one jurisdictions that impose a general income tax, only one, the District of Columbia, fails to tax nonresident income, ${ }^{125}$ a predictable result of the fact that the body that legislates for the District is more representative of nonresidents who work there than of District residents themselves. ${ }^{126}$ The forty states that do tax nonresident income on a broad basis do so in a variety of ways.

My concern here, however, is not with differences in detail but with the key political choices bearing on states' treatment of the nonresident for personal income tax purposes. One critical choice is between a progressive and a proportional income tax system. As suggested above, ${ }^{127}$ such a choice involves a fundamental policy determination whether it is fairer to demand from each taxpayer the same share of his income or to demand increasingly larger shares from those who earn more. Five states have adopted a proportional approach in their income tax systems. ${ }^{128}$ Since rate is then no longer a function of income, the problem of increasing the rate by reference to nontaxables evaporates. The nonresident and the resident simply pay the same portion of their taxable income to the state, at the single rate the state has established.

124. See generally Day, Taxing Interstate Commuters: $A$ New Jersey Experiment Under the United States Constitution, 18 RuTGERs L. REv. 1 (1963). The commuter's tax is no different in principle from those state death taxes designed to absorb the federal estate tax credit for inheritance, estate, or other state succession taxes. 26 U.S.C. \& 2011 (1970). See note 137 infra.

125. D.C. Code ANN. $\S 47-1567$ (1973). However, nonresidents are subject to the District's "Unincorporated Business Tax." D.C. CoDE ANN. § 47-1574 (1973).

126. The recent grant of "home rule" to the District, Pub. L. No. 93-198, 87 Stat. 774 (Dec. 24, 1973), explicitly withholds from the governing council the authority to "impose any tax on the whole or any portion of the personal income, either directly or at the source thereof, of any individual not a resident of the District . . . ." Pub. L. No. 93-198, § 602(a)(5), 87 Stat. at 813.

127. See text accompanying note 83 supra.

128. ILE. REv. STAT. ch. 120, \& 2-201(b) (1973) (2.5 per cent of taxable net income); IND. ANN. STaT. \& 6-3-2-1(a) (Supp. 1973) (2 per cent of adjusted gross income); Mass. ANN. Laws ch. 62, $\$ 4$ (Supp. 1972) (5 per cent of earned income and annuities; 9 per cent of interest, dividends, and net capital gains); MICH. STAT. ANN. \& 7.557(151) (Supp. 1973) (3.9 per cent of adjusted gross income); PA. STAT. ANN. tit. 72, § 7302 (Supp. 1973) (2.3 per cent of specified classes of taxable income). In several instances, this "choice" was compelled by state court decisions holding that an income tax is a property tax and that graduated rates therefore violate the uniformity and equality provisions of state constitutions. See In re Opinion of the Justices, 220 Mass. 613, 108 N.E. 570 (1915); Kelley v. Kalodner, 320 Pa. 180, 181 A. 598 (1935); cf. Thorpe v. Mahin, 43 Ill. 2d 36, 250 N.E.2d 633 (1969), overruling Bachrach v. Nelson, 349 Ill. 579, 182 N.E. 909 (1932). 
The other thirty-five jurisdictions that impose general income taxes on residents and nonresidents have tax systems with at least some measure of progressivity. ${ }^{129}$ Although in several instances the progressive element of the rate structure may be regarded as de minimis, ${ }^{130}$ each of these jurisdictions must determine (and, of course, has by statute declared) whether a nonresident's income tax rate will be based on in-state or on both in-state and out-of-state income. Among these states, only Alaska has refrained from taxing even its residents on income earned from sources outside the state. ${ }^{131}$ Obviously any attempt by Alaska to reckon a nonresident's tax rate with reference to his total income would be improper unless the same were done with respect to residents. The remaining thirty-four jurisdictions, however, tax residents on their income wherever earned and nonresidents on income from sources within the state. ${ }^{132}$ Four of these do in fact look to out-of-state income in fixing a nonresident's income tax rate. ${ }^{133}$ Hence thirty states, although not constitutionally

129. See 1 P-H State and Local Taxes (All States Unit) If 1007 (1974); CCH State TAX Gube (All States Unit) of 15,000, at 1531-34 (1974).

130. Mississippi, for example, imposes an income tax at the rate of 3 per cent on the first $\$ 5,000$ of taxable income and 4 per cent for all taxable income in excess of $\$ 5,000$. Miss. CODE ANN. § 27-7-5 (1972).

131. Alas. Stat. $\$ 43.20 .010$ (a) (1971). Both the measure and rate of the taxes are likewise determined solely on the basis of income from sources within the state.

132. Ala. Code tit. 51, § 377 (1958); ARIz. Rev. Stat. ANN. § 43-102(a) (Supp. 1973); Ark. Stat. ANN. § 84-2003 (Supp. 1973); CAL. Rev. \& TAX Code ANN. § 17041 (Supp. 1974); Colo. Rev. Stat. ANn. §§ 138-1-9, -15 (Supp. 1965); Den. Code ANN. tit. 30, § 1102 (Supp. 1970); GA. Code ANN. \& 92-3101 (Supp. 1973); HAwaII Rev. STAT. \& 235-4 (Supp. 1973); IDaho Code ANN. § 63-3024 (Supp. 1973); Iowa Code § 422.5 (1971); KAN. Stat. ANn. \$§ 79-32,110, 117 (Supp. 1972), 116, 122, 123 (1969); Ky. Rev. Stat. ANn. $\S \S 14.020(1)$, (4) (Supp. 1972); La. Rev. Stat. ANn. \$ 47:31 (1970); ME. Rev. Star. ANN. tit. 36, § 5111 (Supp. 1973); MD. ANN. CoDE art. 81, §§ 280(a), 287, 288, 291(a) (1969); Minn. Stat. AnN. §§ 290.01(22) (1962), .17 (Supp. 1974); Miss. Code AnN. §§ 27-7-5 (1972), -15 (Supp. 1973); Mo. Stat. ANN. §§ 143.041, .121 (Supp. 1974); MoNT. REv. Cones ANN. §§ 84-4902, -4903 (Supp. 1973); NEB. Rev. STAT. § 77-2715 (Supp. 1973); N.M. Stat. ANN. § 72-15A-3 (Supp. 1973); N.Y. TAX LAw \$§ 6Il (1966), 612, 631-32 (Supp. 1973); N.C. GEN. Stat. \& 105-136 (1972); N.D. CENT. CODE §§ 57-38-02, -03 (1972); OHo Rev. CoDe §§ 5747.02, 20 (1973); OrLA. Stat. ANN. tit. 68, §§ 2353(12), 2355(A), 2362 (Supp. 1973); ORE. REv. StAT. § 316.037 (1971); R.I. GEN. LAWS ANN. \$§ 44-30-1, $-12,-32$ (Supp. 1972); S.C. Code \& 65-221 (1962); UTAH Code ANN. §§ 59-14A-5, -11, -15 (Supp. 1973); VA. CodE ANN. \$§ 58-151.013(a), (f) (Supp. 1973); VT. Stat. ANN. tit. 32, $\S \S 5822$ (1970), 5823 (Supp. 1973); W. VA. CoDE ANN. \$§ 11-21-4b, -12 (Supp. 1973), -31 (1966); WIS. STAT. ANN. \$§ 71-.01, -.02 (1969).

133. See note 115 supra. Alaska, when it was still a territory, had adopted a progressive rate structure that assessed nonresidents on their Alaska income at rates determined by their income from all sources. Alas. Sess. Laws 1949, ch. 115, § 5A(a). The provisions are set out and discussed in Alaska S.S. Co. v. Mullaney, 180 F.2d 805, 809 n.1, 822-23 n.23 (9th Gir. 1950). Alaska's present income tax law, however, contains no such provision and imposes a tax on both residents and nonresidents of 16 per cent of a taxpayer's federal tax liability "upon all income derived from sources within the state." AIAS. STAT. \& 43.20.010(a) (1971). Alaska has a particularly troublesome problem in the taxation of nonresidents or part-year residents who come to Alaska during 
compelled to do so, base their progressive rates only on a nonresident's in-state income, despite the fact that doing so deprives them of revenue they would otherwise have collected ${ }^{184}$ and fails to reflect the taxpayer's total ability to pay.

What explanation is there for this self-restraint? It is conceivable that the state legislatures were persuaded by the argument that it is fundamentally inequitable for a state to increase a nonresident's tax bill as a result of activities carried on elsewhere. There are at least three reasons that make this explanation unlikely. First, as discussed in connection with the Wheeler case, ${ }^{135}$ there are equally compelling policy arguments that support such a rate structure. It treats people with the same ability to pay similarly for state tax purposes and does not allow jurisdictional boundaries to provide the multistate taxpayer with an escape from progressivity. Additionally, when forced to choose between fairness to outsiders and increased revenue for themselves,

the warmer months and of merchant seamen based elsewhere who work in Alaskan waters. See Alaska S.S. Co. v. Mullaney, 180 F.2d 805 (9th Cir. 1950); State of Alaska v. Petronia, 69 Wash. 2d 400, 418 P.2d 755 (1966), appeal dismissed, 389 U.S. 7 (1967). In light of this, one must wonder what prompted the Alaska legislature to change its tax laws so as to reduce even further the tax revenues it derives from non- or part-year residents.

134. Arguably, since every state (except Alaska) imposing a general income tax allows its residents a credit for income taxes paid to other states, CCH STATE TAX Guine (All States Unit) If 15-000, at 1543 (1974) (chart), a state's decision to increase its tax rate, and, hence, tax yield, with respect to nonresidents would simply siphon off a corresponding amount of revenue from the nonresident's home state, which would allow him a credit for whatever taxes he paid as a nonresident. But this very likely would not occur to the extent that the taxing state had higher tax rates than the nonresident's home state or taxed some sources of income not taxed by the nonresident's home state. See Note, supra note 13, at 981-85. Moreover, this would clearly not be true of those states that tax nonresidents who are residents of states with no general income tax. A glance at the map reveals that the ten states that apply no general in. come tax of their own, see notes 120-22 supra, are bordered by twenty-nine jurisdictions that do impose such taxes, twenty-seven of which use progressive rates, see notes 128.29 supra and accompanying text, and twenty-three of which look only to in-state income for determining the rate at which a nonresident pays income taxes. These are: Alabama (Florida, Tennessee), Arizona (Nevada), Arkansas (Tennessee, Texas), California (Nevada), Colorado (Wyoming), Delaware (New Jersey), Georgia (Florida, Tennessee), Idaho (Nevada, Washington, Wyoming), Iowa (South Dakota), Kentucky (Tennessee), Louisiana (Texas), Maine (New Hampshire), Minnesota (South Dakota), Mississippi (Tennessee), Montana (South Dakota, Wyoming), New Mexico (Texas), New York (Connecticut, New Jersey), North Carolina (Tennessee), North Dakota (South Dakota), Oklahoma (Texas), Oregon (Nevada, Washington), Utah (Nevada, Wyoming), Virginia (Tennessee). In addition to the individual who lives in a state without a general income tax and works in a state with such a tax, any resident of the former type of jurisdiction deriving income from property owned in the latter type of jurisdiction would in most cases contribute to the aggregate net tax yield of the states were he taxed at progressive rates on the basis of his entire income. Furthermore, the traveling salesman or merchant seaman residing in a state without a general income tax may nevertheless earn income taxable by a number of states that do not border on his own. See State of Alaska v. Petronia, 69 Wash. 2d 460, 418 P.2d 755 (1966), appeal dismissed, 389 U.S. 7 (1967).

135. See text accompanying notes 57-79 suspra. 
the states have not unnaturally tended to give themselves the benefit. of the doubt. ${ }^{130}$ Third, seventeen of the thirty states that have refrained from reckoning their progressive income tax rates in terms of a nonresident's total income wherever earned nevertheless determine their progressive death tax rates in terms of a nonresident decedent's entire estate wherever situated. ${ }^{137}$ There is no meaningful distinction between income and death taxes for purposes of such a rate structure; ${ }^{138}$ thus the disparity is puzzling.

A second possible justification for the states' hesitation to look to a nonresident's out-of-state income for purposes of their progressive rate structure is that doing so would entail administrative burdens that outweigh the revenue that might be gained. This contention does not withstand analysis. Even if one is prepared to argue that minimizing the number of computations required of a nonresident relieves state tax authorities of administrative problems serious enough to justify foregoing otherwise obtainable state revenue, ${ }^{139}$ the truth is that in many instances the nonresident will have had to make such computations anyway. Every one of the thirty states ${ }^{140}$ that permit the nonresident to compute his tax with respect only to in-state income nevertheless requires him to compute the percentage

136. See cases cited in note 104 supra.

137. Ala. Code. tit. 51, § 438 (1958); ARk. Stat. ANN. § 63-104 (1971); Ga. Code ANN. § 92-3402 (1961); Hawair REv. Stat. § 236-14 (Supp. 1973); Iowa Code § 451.2 (1971); KAN. Stat. ANN. § 79-150la (1969), KAN. ADMin. Regs. \$ 92-2-23, reported in 1 CCH Inh. Est. \& Gifr Tax Rep. 27,243 (1966); Ky. Rev. Stat. ANn. \& 140.130 (1971); Minn. Stat. Ann. § 291.34 (1972); Mont. Rev. Codes ANn. \& 91-4411(a) (Supp. 1973); N.M. STAT. ANN. \& 72-33-4 (Supp. 1973); N.Y. TAX LAW \& 960 (1966); N.C. GEN. STaT. § 105-2l (1972); OHIo REv. CODE § 5731.19 (1973); OKLA. STAT. ANN. tit. 68, § 804 (1966); S.C. CODE § 65-481 (Supp. 1971); Utaf Code ANN. \& 59-12-2(2) (Supp. 1973); VA. Code ANN. § 58-193.1 (Supp. 1973).

Many of these statutory provisions are designed principally to take full advantage of the federal estate tax credit allowed for payment of state death taxes. 26 U.S.C. $\S 2011$ (1970). These "sponge" taxes, so denominated because they are designed to "absorb" the federal credit, cf. text accompanying notes 122-24 supra, generally impose a tax equal to the maximum amount of credit allowed under section 2011 of the Internal Revenue Code. With respect to nonresidents, the tax generally equals that proportion of the allowable federal credit defined by the ratio of the property taxable in the taxing state to the value of the entire estate wherever located. Since the federal credit is graduated according to the federal taxable estate, any state tax formula designed to absorb a proportionate part of the credit will have the same effect as the tax formula employed in Wheeler-namely, raising the state tax by considering nontaxables for rate purposes. This assumes, of course, that the nontaxables (for example, out-of-state realty or tangible personalty) constitute part of the taxable estate and that these are sufficient to raise the effective rate of the allowable credit.

138. See Alaska S.S. Co. v. Mullaney, 180 F.2d 805, 822-23 n.23 (9th Cir. 1950); cf. Smith v. Loughman, 245 N.Y. 486, 157 N.E. 753, cert. denied, 275 U.S. 560 (1927).

139. While this is obviously a policy judgment, it is difficult to perceive exactly what administrative problems the legislators might have had in mind, particularly in light of the byzantine complexities that many of these states have without hesitation introduced into other aspects of their tax systems.

140. See text accompanying notes 132-34 supra. 
that his in-state income bears to his total income for purposes of state deductions, exemptions, or credits. ${ }^{141}$ Thus, in most instances the nonresident is required to carry out the very calculations he would have had to make were he compelled to compute his state tax at a progressive rate determined with reference to his total income. In short, an argument based on easing the administrative burden is pure hokum.

Finally, it is possible that states have refrained from taxing nonresidents at a rate determined by their entire income for fear that doing so would precipitate retaliatory action by other states, resulting in higher taxes imposed upon the out-of-state income of their own residents. ${ }^{142}$ Whether such a fear is justified depends upon such factors as whether neighboring jurisdictions imposed an income $\operatorname{tax},{ }^{143}$ the rate structure of such a tax, and whether the state was primarily a source of supply or demand for out-of-state labor and capital.

In sum, while there may be rational explanations for the states' failure to adapt their progressive rate structures to the nonresident's full ability to pay, for the most part such explanations appear to have had little real effect in shaping statutory patterns. More likely, the legislators gave little, if any, thought to considerations such as those raised here. If they had, perhaps they would have done something about the problems involved. If they now do, perhaps they

141. ALA. CodE tit. 51, $\S 385$ (1958), 388 (Supp. 1973) (deductions, exemptions); Ariz. Rev. Stat. ANN. \& 43-128(b) (Supp. 1973) (credits); ArK. Stat. ANN. \$\& 84-2020, -2021(e) (1960) (deductions, credits); CAL. REv. \& TAX CODE ANN. \$§ 17055, 18002(c) (1970) (deductions, exemptions, credits); Colo. REv. STAT. ANN. \& 138-1-15 (Supp. 1965) (deductions, exemptions); DEL. CoDE ANN. tit. 30, \& 1126 (Supp. 1972) (deductions, exemptions); GA. CODE ANN. \& 92-3112(d) (1961) (deductions, exemptions); HAwAII REv. STAT. § 235-5(c) (1968) (deductions); IDAFo CoDE ANN. \$\$ 63-3027(t), -3029(b) (Supp. 1973) (deductions, exemptions, credits); IowA CoDE $\$ 422.9$ (1971) (deductions "fairly and equitably allocable to Iowa under the rules and regulations prescribed by the director"; see Iowa Departmental Rules § 22.9-12 (1971)); KAN. STAT. ANN. \$§ 79-32, 126(b)-127 (1969) (deductions, exemptions); KY. REv. STAT. ANN. \& 141.020(3)(h) (Supp. 1972) (credits); LA. REv. Stax. ANN. \$\$ 47:79(E) (1970), :243 (Supp. 1974) (exemptions, deductions ("ratable portion")); ME. REv. STAT. ANN. tit. 36, § 5144 (Supp. 1973) (deductions); MD. CoDE ANN. art. 81, $\S$ 286(h), 291(a) (1969) (exemptions, deductions, credits); Minn. Star. ANN. \$\$ 290.06(3a)-(c), (7), 081(b) (Supp. 1974) (deductions, credits); Mrss. Code ANN. § 27-7-21(i) (Supp. 1973) (exemptions); MONT. Rev. Codes ANN. \$ 84-4910(i) (1966) (exemptions); N.M. STAT. ANN. \& 72-15A-12 (Supp. 1973) (credits); N.Y. TAX LAW \& 636 (Supp. 1973) (exemptions); N.C. GEN. STAT. \& 105-149(b) (1972) (exemptions); N.D. CENT. CoDE \& 57-38-06.1 (1972) (exemptions); Onlo REv. CoDE \$ 5747.05(A)(2) (1973) (credits); OkLA. Stat. ANN. tit. 68, § 2362 (Supp. 1973) (deductions, exemptions); ORE. REv. STAT. § 316.117 (1971) (deductions, exemptions); S.C. CoDE § 65225(6) (1962) (exemptions); UTAF CoDE ANN. \$ 59-14A-5 (Supp. 1973) (determination of Utah taxable income); VA. CoDE ANN. \& 58-151.013(f), -.015(b) (Supp. 1973) (determination of Virginia taxable income, credits); W. VA. CoDE ANN. \& 11-21-40 (1966) (credits); WIS. STAT. ANN. §§ 71.02(2)(a) (1969), .02(2)(f), (gP) (Supp. 1973) (deductions).

142. The Report of the New Jersey Tax Policy Committee, Part V, Non-Property Taxes in a FaIr and Equitable Tax System 93 (1972) takes this position.

143. See note 134 supra. 
will. The arguments in favor of jurisdictionless ability to pay as the basis of a state tax structure may in many instances outweigh those that can be marshalled against it. However the issue may ultimately be resolved, it is better that the resolution be the outcome of deliberate decision-making rather than the result of unwitting neglect.

\section{Exemptions, Deductions, and Credits}

The considerations underlying the nonresident's relationship to the taxing jurisdiction are germane to several other issues arising in connection with the income taxation of nonresidents. It may therefore be useful to examine briefly, in light of the factors discussed above, some of the recurring problems involving the allowance or disallowance of exemptions, deductions, and credits to nonresidents under state income tax statutes.

The guiding constitutional principles were enunciated in Shaffer v. Carter, ${ }^{144}$ which definitively established the state's right to tax the income of nonresidents, and the companion case of Travis $v$. Yale bo Towne Manufacturing Co. ${ }^{145}$ In Shaffer, the appellant, while broadly challenging the state's power to tax the income of nonresidents, also contended that Oklahoma's statute violated the privileges and immunities and equal protection clauses because it permitted residents to deduct losses wherever incurred but allowed nonresidents to deduct only losses incurred within the state. To this claim the court responded:

The difference, however, is only such as arises naturally from the extent of the jurisdiction of the State in the two classes of cases, and cannot be regarded as an unfriendly or unreasonable discrimination. As to residents it may, and does, exert its taxing power over their income from all sources, whether within or without the State, and it accords to them a corresponding privilege of deducting their losses, wherever these accrue. As to nonresidents, the jurisdiction extends only to their property owned within the State and their business, trade, or profession carried on therein, and the tax is only on such income as is derived from those sources. Hence there is no obligation to accord to them a deduction by reason of losses elsewhere incurred. ${ }^{148}$

On the same day, however, the Court in Travis held unconstitutional the provision of the New York income tax statute that denied to nonresident taxpayers the personal exemption granted resident taxpayers:

Whether they must pay a tax upon the first $\$ 1,000$ or $\$ 2,000$ of income, while their associates and competitors who reside in New York do not, makes a substantial difference. Under the circumstances

144. 252 U.S. 37 (1920).

145. 252 U.S. 60 (1920).

146. 252 U.S. at 57. 
as disclosed, we are unable to find adequate ground for the discrimination, and are constrained to hold that it is an unwarranted denial to the citizens of Connecticut and New Jersey of the privileges and immunities enjoyed by citizens of New York. This is not a case of occasional or accidental inequality due to circumstances personal to the taxpayer . . . but a general rule, operating to the disadvantage of all non-residents including those who are citizens of the neighboring States, and favoring all residents including those who are citizens of the taxing State. ${ }^{147}$

The half century of judicial interpretation and legislative implementation of Shaffer and Travis with respect to the allowance or disallowance of exemptions, deductions, and credits to nonresidents has been marked by confusion and inconsistency. The final section of this article addresses some of the questions raised by these decisions and statutes.

\section{A. Personal Exemptions, Deductions, and Credits ${ }^{148}$}

While the Supreme Court made it clear in Travis that the privileges and immunities clause prohibited the complete denial to nonresidents of personal exemptions allowed residents, it left unanswered the question whether the taxing state must grant nonresidents the full exemptions allowed residents or may instead grant only that portion of the exemption defined by the ratio of the nonresident's instate income to his income from all sources. Although some states allow the nonresident the full exemption, ${ }^{149}$ most require that it be proportionately reduced. ${ }^{150}$ The case law on the issue is sparse, divided, and unilluminating. ${ }^{151}$

The essential question is whether a proportional exemption, which in absolute terms is less than the exemption granted residents, operates to the "disadvantage" of nonresidents. ${ }^{152}$ The answer depends on what criterion one uses to determine whether residents and nonresidents are receiving equal treatment. If the issue is framed in terms of the state's power to tax, one can argue that the

147. 252 U.S. at 80-81.

148. This category includes all allowances, whether denominated exemptions, deductions, or credits, that permit the taxpayer to reduce his taxable income or his tax solely on the basis of his personal status and without regard to any expenses incurred.

149. See Hatwair Rev. Stat. § 235-5(c) (1968); Me. Rev. Stat. ANn. tit. 36, § 5145 (Supp. 1973); W. VA. CODE ANN. \& 11-21-36 (1966).

150. See, e.g., ARk. StAT. ANN. \& 84-2021(e) (1960); Dec. Code ANN. tit. 30, \& 1126 (Supp. 1972); Inc. REv. STAT. ch. 120, § 2-204 (1973). See also note 141 supra.

151. Compare Reynolds Metal Co. v. Martin, 269 Ky. 378, 384, 402, 107 S.W.2d 251, 252-53, 263 (Spec. Ct. App. 1937) with State v. Burnett, 200 Ark. 655, 140 S.W.2d 673 (1940); cf. State ex rel. Haworth v. Berntsen, 68 Idaho 539, 200 P.2d 1007 (1948); State ex rel. McCulloch v. Ashby, 73 N.M. 267, 387 P.2d 588 (1963); McCutchan v. Oklahoma Tax Commn., 191 Okla. 578, 132 P.2d 337 (1942).

152. Travis v. Yale \& Towne Mfg. Co., 252 U.S. 60, 81 (1920). 
proportionate exemption simply recognizes the more limited jurisdiction that the state exercises over the nonresident's income, and that the difference in treatment is therefore rational and fair. ${ }^{153}$ On the other hand, it can be argued that the jurisdictional bases for taxing residents and nonresidents are not relevant to the considerations bearing on a state's decision to grant personal exemptions.

Personal exemptions represent a political determination that a portion of a taxpayer's income should be immune from tax liability solely on the basis of his personal status and without regard to any expenses he might have incurred. They reflect the view that until a taxpayer's earnings reach a certain level he ought not be required to contribute to the costs of government. In addition, because of the problems that would arise if individuals above a certain income level were required to pay taxes on all their income, including that below the exemption level, personal exemptions are almost invariably granted to all taxpayers, regardless of their income. ${ }^{154}$

If the issue is reframed in light of the purpose of granting personal exemptions, the search for a persuasive justification for reducing the nonresident's exemption on the basis of income earned elsewhere becomes more troublesome. Since the amount of income a resident earns plays no role in determining whether he receives a full exemption, it should not play any role in determining whether a nonresident receives a full exemption. Moreover, it may be suggested that the source of one's income bears no more rational relationship to the purposes of granting personal exemptions than does its amount. Indeed, the fact that the resident's personal exemption does not vary according to the source of his earnings demonstrates that the state has determined that there is no necessary relationship between the amount of the exemption and the source of the taxpayer's income..$^{155}$ (1959).

154. Blum \& Kalven, The Anatomy of Justice in Taxation, in Occastonar Papers FROM THE LAW SchoOL OF TFE UNIVERSTTY OF ChICAGo 11-12 (1973). Blum and Kalven provide the following illustration of the effect of giving an exemption only to those below the cutoff point and none to those above the cutoff point:

[A]ssume an exemption of $\$ 5,000$ and a flat rate of 25 percent. A man with an income, say, of $\$ 4,000$ or $\$ 4,500$ or $\$ 5,000$ will pay nothing in taxes; but a man with a slightly larger income, say, of $\$ 5,100$ or $\$ 5,500$ or $\$ 6,000$ will end up literally worse off after taxes than if he initially had had an income under $\$ 5,000$. Indeed, the system will find itself using a marginal rate of tax on that additional $\$ 100$, $\$ 500$, or $\$ 1,000$ that is over 100 percent. Id. at 12.

155. Solomon, Nonresident Personal Income Tax: A Comparative Study in Eight States, 29 FordhAMr L. REv. 105 (1960), declares flatly that "[p]ersonal exemptions, have no relation to ... the source of [a taxpayer's] income," and construes Travis as holding that "a state must afford nonresidents and residents the same personal exemptions." Id. at 108. For reasons set forth in the text, this would appear to oversimplify the problem. See McCutchan v. Oklahoma Tax Commn., 191 Okla. 578, 132 P.2d 337 (1942) (per- 
On the other hand, if source is a fair measure of a nonresident taxpayer's relationship to the state, as has generally been assumed, it is not unreasonable to argue that, to the extent that his activities are carried on elsewhere, his need for and claim to a minimum level of income free from tax in the taxing jurisdiction is accordingly diminished.

Another approach to the question is grounded in neither the jurisdictional bases for the taxation of nonresidents nor the underlying purposes of the personal exemption. One can examine the question from the standpoint of achieving an equality of tax rates between residents and nonresidents. Depending on whether one defines rate equality with respect to income from all sources or with respect only to income taxable by the state-a distinction that lay at the heart of the dispute in Wheeler-the proportional personal exemptions for nonresidents may or may not find support. If rate equality is viewed in terms of a taxpayer's income from all sources, it is furthered more by the use of proportional exemptions than by the use of full exemptions. ${ }^{156}$ If, however, rate equality is viewed in

sonal exemptions apportioned to income earned within state for residents and nonresidents alike); see also Culp, supra note 153, at 292-93.

156. The following example illustrates the point: Assume the effective tax rate (whether proportional or graduated) on a resident and nonresident taxpaycr, cach earning $\$ 10,000$, is 10 per cent without consideration of any exemptions. Assume further that the nonresident earns only half his income in the taxing state and that a full personal exemption amounts to $\$ 1,000$. The effect of allowing the nonresident a full or a proportional exemption is as follows:

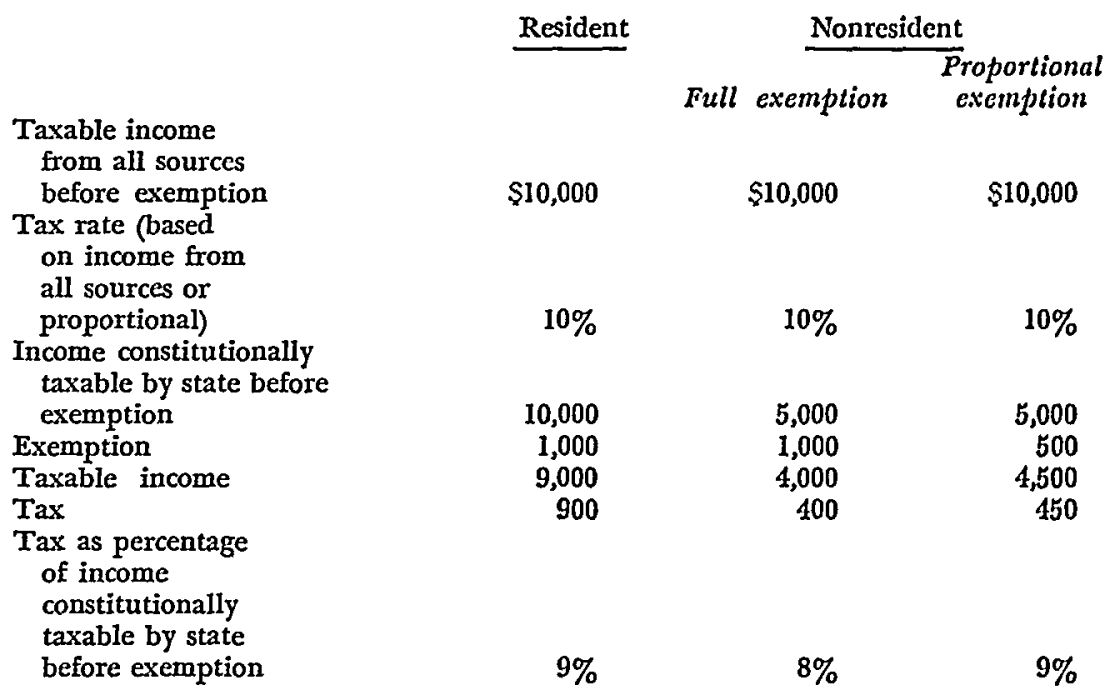

Moreover, if allowing a nonresident a full exemption in a graduated rate structure were to lower the nonresident's effective tax rate, this would exacerbate the rate incquality between resident and nonresident in terms of their total income. This problem, of course, would not arise in a proportional system. 
terms solely of the taxpayer's income that is constitutionally taxable by the state, full exemptions for nonresidents obviously have a greater tendency to achieve equality than proportional exemptions. ${ }^{157}$ While framing the question in terms of rate equality provides no definitive answer, identification of the assumptions about rate equality that underlie-or ought to underlie- -a state's tax system may suggest a resolution of the issues involved. ${ }^{158}$

157. On this assumption, the appropriate comparison would be between the hypothetical nonresident in note 156 supra and a resident who earned $\$ 5,000$ taxable income from all sources before an exemption.

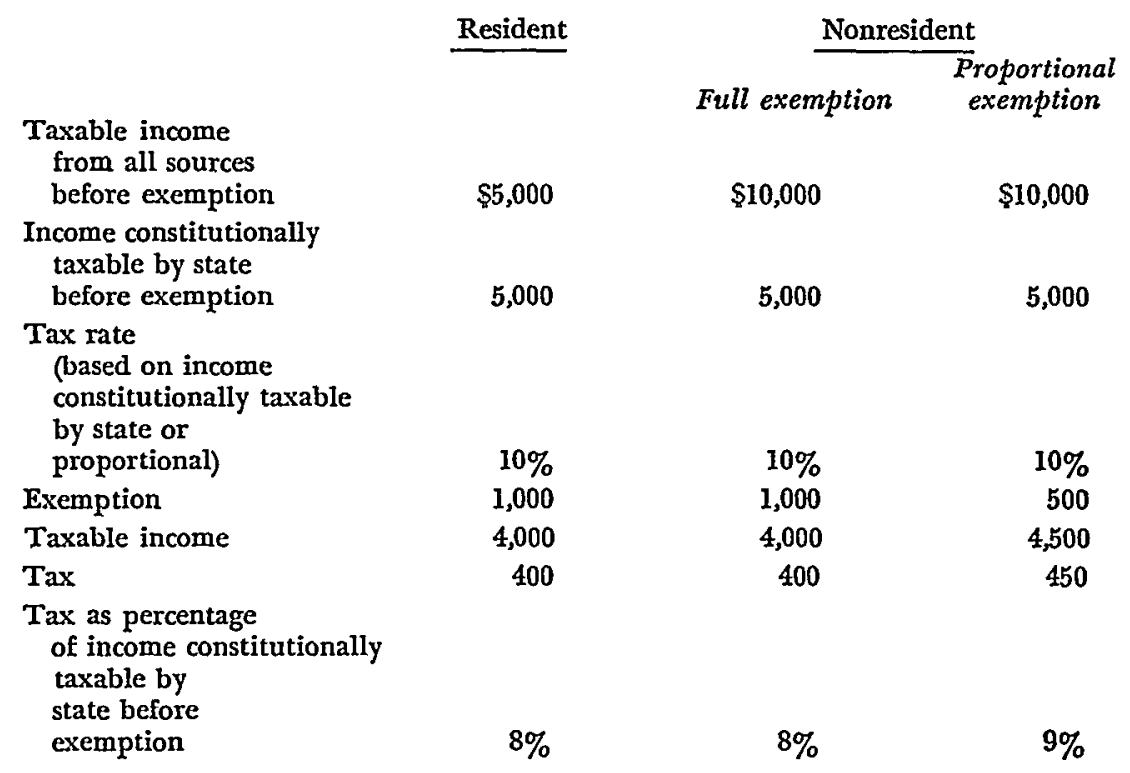

158. The discussion in the text has focused on the impact of the personal exemption upon the effective rate at which an individual pays his tax. A related question-though one not limited to the treatment of residents vis-à-vis nonresidents-is the impact of marginal rates in a progressive tax system upon the effect of a personal exemption. The Report of The New Jersey TAX Policy Commitee, supra note 142, summarized the problem:

[P]erhaps the most important question concerning the exemption is how it should be implemented, through a deduction or a tax credit. By allowing the exemption in the form of a deduction, the tax benefit of the deduction varies as income increases, being the amount of the deduction times the marginal tax rate. Accordingly, as income increases the graduated rate results in the tax benefit of the deduction being increased. A method of controlling the effect of having a deduction coming off the highest rate bracket rather than the lowest is to state the deduction as a credit. Thus, the tax benefit from the personal exemption would be the same for all families of the same size. What this means is that the credit can be fixed in conjunction with the tax rate so as to exempt a fixed amount of income for persons in various family situations.

Id. at 9l. A few states have framed their personal exemptions as tax credits, see, e.g., ARK. Stat. ANN. § 84-2021 (Supp. 1973); Iowa Code \& 422.12 (1971); Ky. REv. Stat. ANN. \& 141.020(3) (Supp. 1972), but the great majority allow a deduction from gross income. See also Weidenbaum, The Advantages of Credits on the Personal Income Tax, 42 Geo. WAsh. L. REv. 516 (1974). 


\section{B. Deduction for Expenses}

1. Expenses Incurred in Connection with the Production of Income

Shaffer v. Carter ${ }^{159}$ established and Travis v. Yale or Towne Manufacturing $C o .{ }^{160}$ reiterated the principle that a state may limit the nonresident's deduction of expenses, losses, and the like to those incurred in connection with the production of income within the taxing state. At least insofar as the expenses relate to the nonresident's efforts to earn income, the proposition is eminently reasonable, because the state's jurisdiction to tax such income is similarly confined. Most state income tax statutes specify the criteria and methods the nonresident taxpayer must follow in allocating or apportioning to the taxing state expense deductions associated with income producing activities in that state. ${ }^{101}$ While the relation of a particular expense item to activity in the taxing state may present troublesome factual questions, the controlling legal doctrine is both settled and sensible.

\section{Expenses Not Incurred in Connection with the Production of Income}

When we consider expenses not incurred in connection with the production of income, the controlling legal doctrine may be just as settled, but one may question whether it is as sensible. Shaffer and Travis, read literally, justify a state's refusal to allow a nonresident even a proportionate share of the various personal deductions allowed residents: "That there is no constitutional discrimination against citizens of other States in confining the deduction of expenses, losses, etc., in the case of non-resident taxpayers, to such as are connected with income arising from sources within the taxing State, likewise is settled by [Shaffer v. Carter]." 102 A number of states have invoked this language to deny nonresidents personal deductions, ${ }^{163}$ and state courts have predictably sustained such legislation..$^{104}$

159. 252 U.S. $37,56-57$ (1920).

160. 252 U.S. 60, 75-76 (1920).

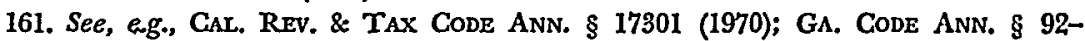
3112(d) (1961); IowA CoDE \& 422.9 (1971). See also note 142 supra.

162. Travis v. Yale \& Towne Mfg. Co., 252 U.S. 60, 75-76 (1920).

163. See, e.g., Mont. Rev. Codes Ann. \& $84-4907$ (Supp. 1973); N.G. Gen. STAT. \$ 105-147(18) (1972); S.C. CODE § 65-264.1 (Supp. 1973). However, many states allow the nonresident to dedict a proportionate share of his personal expenses. See, e.g., Der. Code ANN. tit. 30, § 1124 (Supp. 1970); GA. CODE ANN. \$ 92-3112(d) (1961); Hawair REV. STAT. \& 235-5(c) (1968).

164. See Goodwin v. State Tax Commn., 286 App. Div. 694, 146 N.Y.S.2d 172 (1955), affd. mem., I N.Y.2d 680, 150 N.Y.S.2d 203, 133 N.E.2d 711, appeal dismissed, 352 U.S. 805 (1956); Stiles v. Currie, 254 N.C. 197, 118 S.E.2d 428 (1961); Wilson v. Department of Revenue, - Ore. -, 514 P.2d 1334 (1973), appeal dismissed, 42 U.S.L.W. 3608 (U.S. 
Nevertheless, serious questions may be raised concerning the logic and fairness of a total denial of certain personal deductions. Although it makes perfect sense for a state to deny the nonresident taxpayer a deduction for an expense incurred in connection with the production of income outside the state, because such income is not taxable by the state and at the same time to allow a resident taxpayer a deduction for expenses incurred in connection with the production of income wherever earned, because all such income is taxable by the state, it does not follow that the allowability of deductions that are granted for reasons having nothing to do with income producing activity should also be determined by considerations relating to jurisdiction to tax income.

There is, of course, more to be said for a state's decision to deny personal deductions to nonresidents than the Supreme Court's declaration that a state may restrict a nonresident's deductions to those connected with income arising from sources within the state. Whether or not the Supreme Court intended its comments in Shaffer and Travis to apply to personal expense deductions, ${ }^{165}$ a persuasive case can be made that the refusal to grant personal deductions to nonresidents is a legitimate expression of the different relationship of the resident and nonresident taxpayer to the taxing state. ${ }^{168}$ The rationale was well stated in Goodwin $v$. State Tax Commission, ${ }^{167}$ involving the denial by New York State to a New Jersey resident of deductions for real estate taxes, mortgage interest, medical expenses, and life insurance premiums: "The factor of residence has an obvious connection with the allowance of the deductions of a personal character which are under consideration here. The expenditures are properly associated with the place where the taxpayer resides. They

April 29, 1974) (No. 73-1126); Berry v. State Tax Commn., 241 Ore. 580, 397 P.2d 780 (1964), appeal dismissed, 382 U.S. 16 (1965).

165. In Goodwin v. State Tax Commn., 286 App. Div. 694, 146 N.Y.S.2d 172 (1955), affd. mem., 1 N.Y.2d 680, 150 N.Y.S.2d 203, 133 N.E.2d 711, appeal dismissed, 352 U.S. 805 (1956), the court noted that one of the issues presented to the Supreme Court in Travis was the alleged discrimination against the nonresident who, unlike the resident, was forbidden from deducting real estate taxes on his home outside the taxing state. The New York court read the Supreme Court's statement in Travis, see text accompanying note I62 supra, as authoritatively settling the issue of whether the state could constitutionally deny personal deductions to nonresidents, 286 App. Div. at 698, 146 N.Y.S.2d at 177, although it went on to consider the problem on broader grounds. However, nothing in either the Shaffer or Travis opinions indicates whether the Court was addressing itself to personal as well as business deductions, and at least one judge has found it "impossible to determine whether the opinions referred to business losses and expenses or personal expenses." Berry v. State Tax Commn., 241 Ore. 580, 586, 397 P.2d 780, 783 (1964) (dissenting opinion), appeal dismissed, 382 U.S. 16 (1965).

166. See text accompanying notes 57-68 supra.

167. 286 App. Div. 694, 146 N.Y.S.2d 172 (1955), affd. mem., 1 N.Y.2d 680, 150 N.Y.S. 2d 203, 133 N.E.2d 711, appeal dismissed, 352 U.S. 805 (1956). 
all relate to the personal activities of the taxpayer and his personal activities must be deemed to take place in the State of his residence, the State in which his life is centered."168 The court's statement reveals both the strengths and weaknesses of the rationale for disallowing the deductions. Undoubtedly, residence has "an obvious connection" with the personal activities of a taxpayer. This provides a basis for distinguishing between residents and nonresidents on grounds rationally related to the purposes underlying the grant of personal deductions. But there is nothing that compels the conclusion that this "obvious connection" is in all instances an exclusive one. Medical expenses may be regarded as "related" to all of a taxpayer's activities, and taxes on personal purchases or entertainment may be "deemed to take place" in the state where the purchases are made or the entertainment is enjoyed as much as in the state of residence.

The attempt to analyze the allowability of deductions to nonresidents entirely on the basis of a personal/business dichotomy thus paints with too broad a brush. Indeed, Travis itself demonstrates that the distinction cannot explain the results in all cases. Although the provision struck down there had denied personal exemptions rather than personal deductions to nonresidents, ${ }^{160}$ the decision at minimum reveals that there are limits to the theory that nonresidents may be denied tax benefits permitted residents on the grounds that such benefits have no connection with income earned within the state and may be characterized as "personal." Perhaps a more equitable approach to determining whether the nonresident should be allowed

168. 286 App. Div. at 701, 146 N.Y.S.2d at 180.

169. Travis should be contrasted in this respect with Shaffer v. Carter, 252 U.S. 37 (1920), which can be read as indicating that states may deny personal deductions to nonresidents (but see note 165 supra and accompanying text). To be sure, there are a number of distinctions that can be made between personal exemptions and itemized personal deductions: The former are allowed to all taxpayers, at a flat amount, without regard to any expenditures he might make; the latter are allowed on a selective basis, in differing amounts, to those taxpayers who make specific expenditures. Also, the severity and extent of the impact of denying nonresidents exemptions are probably greater than the impact of denying them personal deductions. But query whether the apparently inconsistent position taken by the Court with respect to personal exemptions and deductions can be justified. The court in Goodwin, while noting that the Supreme Court saw no inconsistency between its Travis and Shaffer opinions, 286 App. Div. at 703, 146 N.Y.S.2d at 181, nevertheless tried to justify the distinction on the ground that personal exemptions must be considered in terms of rate and that the substance of Travis is that a state cannot constitutionally tax the income of nonresidents at higher rates than it taxes the income of residents. $286 \mathrm{App}$. Div. at 702, 140 N.X.S.2d at 181. See text accompanying notes 148-58 supra. The Goodwin court did, however, obliquely acknowledge the inconsistency:

It may well be that, if the question were reconsidered today in the light of the subsequent extension of State income tax laws and if all the considerations here canvassed were brought before the Supreme Court, a different decision might be reached as to the validity of the distinction between residents and nonresidents with respect to the allowance of personal exemptions.

286 App. Div. at 703, 146 N.Y.S,2d at 181-82. 
deductions for his personal expenses would be to examine each expense on an individual basis: Those uniquely related to the state of residence would be denied, and those related to all of the taxpayer's activity would be allowed in the proportion that the activity, as measured by his income, was carried on in the taxing state.

Such a refinement in a state's policy of allowing personal deductions to nonresidents would not call for herculean effort. It would require only a series of specific determinations concerning the particular deduction under consideration. ${ }^{170}$ One might deny a deduction for real estate taxes paid on out-of-state property but allow one, at least in part, for sales taxes on personal purchases in the state. ${ }^{171}$ One might allow or disallow a deduction for interest paid on a personal loan depending on whether the purpose of the loan was peculiarly related to the taxpayer's activity in the state. ${ }^{172} \mathrm{~A}$ strong case can also be made for at least partial allowance of medical expense deductions to nonresidents. Not only may such expenses "be regarded as related to all of the taxpayer's activities, wherever engaged in ..."173 but also they arguably relate to his income producing ability in the state: " $[\mathrm{I}] \mathrm{n}$ effect, his medical expenditures are made in part in an effort to enable the taxpayer to continue to be income-producing, without regard to where the income may be produced."174 Although one might dismiss the latter rationale as a quibble over the classification of medical expenses as business or personal deductions, ${ }^{175}$ it does suggest the illogic of classifying medical expenses as "personal" and denying them simply on the basis of the label affixed.

In short, while the complete denial of personal deductions to nonresidents by the taxing state may be constitutionally permissible,

170. This is precisely what Solomon, supra note 155 , at $115-20$, did with respect to deductions allowed under the New York State income tax law as it then stood. The present statute allows the nonresident a proportionate share of his itemized deductions, N.Y. TAX LAW § 635 (1966).

171. Compare Anderson v. Tiemann, 182 Neb. 393, 404-08, 155 N.W.2d 322, 330-32 (1967) (upholding denial of "food sales tax credit" to nonresidents on ground that "food purchases for personal use are so closely related to the state of residence ... that any ... credit ... should be allowed only by the state of residence ....").

172. See Solomon, supra note 155 , at 117 .

173. Id. at 118, quoting FEDERAL BAR AssN. OF NEW York, NEw JERSEX AND Connecticut, Report on New York State Taxation on INTRa-STate Income of NoNRESIDENTS 11 (1958).

174. Id.

175. The court in Berry v. State Tax Commn., 241 Ore. 580, 397 P.2d 780 (1964) appeal dismissed, 382 U.S. 16 (1965), while denying the nonresidents' claim that they be allowed to deduct medical expenses on the ground that the "facts indicated that the income was not dependent upon the health or earning power of the taxpayers," nevertheless explicitly left open "the question whether or not in a proper case medical expenses might be 'connected with' income." 241 Ore. at 582, 397 P.2d at 781. 
and in many cases justifiable, a state could adopt a more discriminating and equitable approach to the problem without great difficulty.

\section{The Standard Deduction}

The vast majority of state income tax statutes provide the taxpayer with the option of taking a standard deduction, based on a percentage of his income up to a fixed dollar limit, in lieu of itemized personal expense deductions. ${ }^{176}$ While nonresidents are generally permitted to elect the standard deduction, ${ }^{177}$ they are not treated uniformly under the various statutory provisions, which may be divided into two groups. The first group treats the nonresident as if he were a resident, but with respect only to his in-state earnings: The nonresident is allowed to apply the statutory percentage to his in-state income up to the established dollar ceiling. ${ }^{178}$ The second group requires the nonresident to prorate his standard deduction, calculated on his income from all sources, in the proportion that his in-state income bears to his income wherever earned.170

There can be little complaint about the first type of provision. Since the state has decided to use a percentage of income as the appropriate measure of the deduction, it may quite reasonably limit the scope of the deduction to the income over which it has tax jurisdiction. In this way both resident and nonresident receive identical treatment in terms of a rational criterion, namely, income taxable by the state. The point can be made that such a provision overrepresents the deductions to which a nonresident has a legitimate claim since it grants him the same standard deduction as a resident, who might have been entitled to a variety of itemized personal deductions unavailable to the nonresident. ${ }^{180}$ Such criticisms, however, miss the mark. The standard deduction is by definition an effort to provide the taxpayer with a simple means of calculating the deductions that

176. CGH State TAX Guide (All States Unit) of 15-000, at 1542 (1974). A number of states, following the federal model, INT. REv. CoDE of 1954, \& 141, also allow the taxpayer a minimum standard deduction or a low income allowance. See, e.g., N.X. TAx LAW §§ 614, 634 (Supp. 1973); VA. CodE ANN. § 58-151.013(d)(2) (Supp. 1973).

177. See notes 178-79 infra and accompanying text; but see CoLo. REv. STAT. ANN. § 138-1-15(8) (Supp. 1965) (nonresidents mi:st itemize deductions, though residents may elect standard deduction).

178. See, e.g., ALA. Code tit. 51, \& 385(4) (Supp. 1973); N.X. TAX LAW \& 634 (Supp. 1973); W. VA. CODE ANN. \& 11-21-34 (1966).

179. See, e.g., GA. Code ANN. \& 92-3112(d) (1961); OKLA. STAT. ANN. tit. 68, \& 2362(2) (Supp. 1973); ORE. REV. STAT. \& 316.117 (1973). Such an approach is an outgrowth of the fact that many state income tax statutes use federal definitions of income and deductions as the starting point for the computation of their tax base. See P-H STATE AND Local TAXES (All States Unit) \& 1002 (1974). Some reduction in the standard deduction for the nonresident is thus required to reflect that portion of the nonresident's federal income that is taxable by the state.

180. See text accompanying notes 162-75 supra. 
he may claim. The measure is admittedly rough and no attempt is made to draw fine lines between the specific deductions to which a nonresident is or is not actually entitled. In light of their purposes and effect, these deduction provisions are unobjectionable.

The same cannot be said, however, with respect to those provisions that require the nonresident to prorate his standard deduction, calculated on the basis of his income from all sources, according to the ratio that his in-state income bears to his total income. These operate no differently from the provisions discussed above until the dollar amount of the nonresident's percentage standard deduction reaches the statutory maximum; however, once the ceiling applies, the nonresident is no longer treated on the same basis as the resident in terms of income taxable by the state. ${ }^{181}$ This hardly seems equitable in light of the purpose of the standard deduction. If a percentage of income taxable by the state is a fair measure of the resident's standard deduction, why should it not also be a fair measure of the nonresident's standard deduction? The analogy to personal exemptions or itemized expenses, which arguably should be prorated, ${ }^{182}$ is not compelling. In those instances the premise is that the exemption or deduction relates to all of a taxpayer's activities, only part of which are carried on in the taxing state, and that proration is necessary accurately to reflect in-state activity. By contrast, the standard deduction is explicitly keyed to income whose source has already

181. The following example illustrates the point: Assume two states have a standard deduction of 10 per cent or $\$ 1,000$, whichever is less. State $A$ allows the nonresident to apply the percentage and maximum directly to income earned in the state; State $B$ requires the nonresident to calculate his deduction on the basis of his income from all sources and then take a proportionate deduction in the ratio of in-state income to income from all sources. The impact of such provisions on the resident and nonresident taxpayer, whether the comparison is based on the nonresident's in-state income (Resident $\# 1$ ) or on the nonresident's income from all sources (Resident $\# 2$ ), is different, as shown below:

\begin{tabular}{|c|c|c|c|c|c|c|}
\hline \multirow{3}{*}{$\begin{array}{l}\text { Income from } \\
\text { all sources }\end{array}$} & \multicolumn{2}{|c|}{ Resident \#1 } & \multicolumn{2}{|c|}{ Resident \#2 } & \multicolumn{2}{|c|}{ Nonresident } \\
\hline & (a) & $\$ 2,500$ & (a) & $\$ 5,000$ & (a) & $\$ 5,000$ \\
\hline & (b) & 5,000 & (b) & 10,000 & (b) & 10,000 \\
\hline & (c) & 7,500 & (c) & 15,000 & (c) & 15,000 \\
\hline & (d) & 10,000 & (d) & 20,000 & (d) & 20,000 \\
\hline \multirow[t]{4}{*}{ Instate income } & \multirow{4}{*}{\multicolumn{2}{|c|}{$\begin{array}{l}\text { Irrelevant for } \\
\text { purpose of } \\
\text { resident's stan- } \\
\text { dard deduction }\end{array}$}} & \multirow{4}{*}{\multicolumn{2}{|c|}{$\begin{array}{l}\text { Irrelevant for } \\
\text { purpose of } \\
\text { resident's stan- } \\
\text { dard deduction }\end{array}$}} & (a) & 2,500 \\
\hline & & & & & (b) & 5,000 \\
\hline & & & & & (c) & 7,500 \\
\hline & & & & & (d) & 10,000 \\
\hline \multirow{4}{*}{$\begin{array}{l}\text { State } A \\
\text { standard } \\
\text { deduction }\end{array}$} & (a) & 250 & (a) & 500 & (a) & 250 \\
\hline & (b) & 500 & (b) & 1,000 & (b) & 500 \\
\hline & (c) & 750 & (c) & 1,000 & (c) & 750 \\
\hline & (d) & 1,000 & (d) & 1,000 & (d) & 1,000 \\
\hline \multirow{4}{*}{$\begin{array}{l}\text { State } B \\
\quad \text { standard } \\
\text { deduction }\end{array}$} & (a) & 250 & (a) & 500 & (a) & 250 \\
\hline & (b) & 500 & (b) & 1,000 & (b) & 500 \\
\hline & (c) & 750 & (c) & 1,000 & (c) & 500 \\
\hline & (d) & 1,000 & (d) & 1,000 & (d) & 500 \\
\hline
\end{tabular}

182. See text accompanying notes 153, 156, 159-61, 169-75 supra. 
been identified. For the state to insist that the nonresident further reduce his standard deduction below the level represented by his in-state income by calculating it as a proportionate share of his standard deduction based on his income from all sources is anomalous and, perhaps, unconstitutional. ${ }^{183}$

\section{Credits for Taxes Paid to Other States}

With the single exception of Alaska, every state that imposes a general income tax allows its residents a tax credit for taxes paid to other states. ${ }^{184}$ Less than half of these jurisdictions, however, allow such a tax credit to nonresidents. ${ }^{185}$ Furthermore, most of those states that do allow the credit to nonresidents condition its grant on the reciprocity of the nonresident's home state. ${ }^{186}$ These credit provisions thus raise two questions relating to the equitable tax treatment of nonresidents: whether it is justifiable to deny a credit to nonresidents while granting one to residents and whether it is reasonable to condition the nonresident's credit on the existence of reciprocal legislation in his home state. ${ }^{187}$

The case against the constitutionality of denying credits only to nonresidents follows naturally from the preceding discussion. Because the discrimination is self-evident, the issue is whether there is an "adequate ground" for it. ${ }^{188}$ While the Court's approval in Shaffer and Travis of provisions limiting a nonresident's deductions to those connected with income earned in the state might justify a proportional restriction on a nonresident's tax credit, one can argue that it provides no support for complete denial of the credit. Every state but one taxes its residents on income from all sources; ${ }^{180}$ thus the denial of a credit to nonresidents virtually guarantees that they will be denied a credit for taxes paid to their state of residence but levied in part upon income earned in the state of nonresidence. It therefore

183. See Toomer v. Witsell, 334 U.S. 385 (1948); Travis v. Yale \& Towne Mfg. Co., 252 U.S. 60 (1920).

184. CCH State Tax Guine (All States Unit) If 15-000, at 1543 (chart) (1974), see, e.g., IdAHo Code ANN. \$ 63-3029 (Supp. 1973); IrL. REv. Stat. ch. 120, § 6-601(3) (1973).

185. CCH State Tax Gume (All States Unit) \ 15-000, at 1543 (chart) (1974). Sce, e.g., IND. ANN. Stat. \$ 6-3-3-3 (1972); MD. Code ANN. art. 81, § 291(a) (1969).

186. CCH State Tax Guide (All States Unit) 15-000, at 1543 (chart) (1974). See, e.g., N.M. Stat. ANN. \& 72-15A-12 (Supp. 1973); VA. CodE ANN. § 58-151.015 (Supp. 1973).

187. See Culp, supra note 153, at 293-94. This is not to suggest that there are not numerous other issues raised by the variety of conflicting credit provisions. See Note, supra note 13, at 981-86; see also J. HELIERSTEIN, supra note 11, at 620-21. The discussion here, however, is limited to the legality and fairness of the disparate treatment of residents and nonresidents.

188. Travis v. Yale \& Towne Mfg. Co., 252 U.S. 60, 80 (1920).

189. See note 132 supra. 
cannot be suggested that such denial relates only to taxes that are not "connected" with income arising from sources in the taxing state. One can thus contend that Travis compels the conclusion that " $[t]$ his type of discrimination would seem to be without adequate foundation ... , "190 because it is "a general rule, operating to the disadvantage of all non-residents . . . and favoring all residents."191

The conclusion, however, is far from inescapable. First, to the extent that the state of residence taxes extraterritorial income, it is arguably imposing a "personal" tax that relates only to the taxpayer's state of residence. ${ }^{192}$ Since it is solely with respect to this "extraterritorial" income, which is in-state income to the state of nonresidence, that the nonresident has even a colorable claim to a credit, one can assert with some justification that the state of nonresidence is under no obligation to grant nonresidents a credit even though it is granted to residents. More importantly, and beyond the technically defensible arguments that may be offered on both sides of the question, there are broader considerations that should be weighed in evaluating the fairness of the denial of credits to nonresidents. Tax credits, after all, are designed principally to relieve the taxpayer of the burden of taxation of the same income by two sovereigns. To examine the credit issue in terms of a single state's treatment of the resident and nonresident may therefore be analytically myopic, however justifiable in terms of established constitutional criteria.

The critical question thus becomes whether the taxing state's denial to a nonresident of a credit that is granted to a resident burdens the former with double taxation while relieving the latter. The answer depends on whether the nonresident's home state grants him a credit for taxes paid to other states. If it does, the effect of the failure of the state of nonresidence to offer a credit will, in principle, be offset by the diminution of the nonresident's tax bill in his home state. ${ }^{193}$ Since the allowance of credits for income paid to other states by the state of the taxpayer's residence is nearly universal, the nonresident, though denied a credit for taxes paid to his home state, will nevertheless escape double taxation. ${ }^{194}$ As a practical matter, then,

190. Culp, supra note 153 , at 294.

191. Travis v. Yale \& Towne Mfg. Co., 252 U.S. 60, 81 (1920).

192. See text accompanying notes 65-68 supra; see also Fisher, supra note 68.

193. Because of the differences between state tax systems in terms of taxable income, deductions, rates, and the like, and because of the statutory limitations on the amount of the tax credit permitted under various provisions, the correspondence between one state's tax and another state's credit is often less than precise. See Note, supra note 13, at 981-86.

194. The nonresident whose home state imposes no income tax would not confront the double taxation problem in the first place. 
the widespread practice of granting credits to residents removes or at least substantially reduces the burden potentially imposed by the denial of tax credits to nonresidents.

One might assert, however, that the determination whether there is an unconstitutional discrimination against nonresidents cannot rest on so ephemeral a basis as the existing pattern of state legislation. Yet, in light of the inconclusiveness of the constitutional dialogue on the issue, ${ }^{195}$ it is not unreasonable to refrain from condemning these provisions in the absence of some indication that nonresidents are in fact being prejudiced under them. ${ }^{100}$ While there are inequities resulting from the "conflicting crediting devices and the wide variation in their scope," 197 they are not problems that grow out of explicit differences in the treatment of residents and nonresidents in statutory provisions. They are instead a function of a multiplicity of independent taxing jurisdictions whose statutes were not designed with the plight of the multistate taxpayer as their principal concern. Such problems can best be solved by greater uniformity in state legislation. ${ }^{198}$

\section{Conclusion}

Two of the principal problems that legislators confront in considering tax legislation are how to raise sufficient revenue to meet the community's needs and how to do so in a manner that corresponds to the community's sense of fairness. These problems are often exacerbated when they must be solved in the framework of a multistate system where all taxpayers do not enjoy the same jurisdictional relationship to the taxing state. The initiative taken by Vermont and several other states with respect to the taxation of a nonresident's income at rates determined by income from all sources suggests that many states have the rare opportunity to provide for additional revenue in a manner that arguably makes the system fairer than it was before. The considerations underlying the state's jurisdiction to tax the income of residents and nonresidents also suggest relevant, but not necessarily dispositive, criteria for determining the appropriate treatment of nonresidents under provisions in state income tax statutes relating to exemptions, deductions, and credits.

\footnotetext{
195. See text accompanying notes 188-92 supra; with respect to the justifiability of conditioning the nonresident's credit on reciprocal legislation in his home state, com. pare Bachrach v. Nelson, 349 Ill. 579, 596, 182 N.E. 909, 915-16 (1932) with Clement v. Stone, 195 Miss. 770, 13 S.2d 647, affd., 195 Miss. 774, 15 S.2d 517 (1943). Sce also Culp, supra note 153, at 294; Starr, supra note 19, at 400-03.

196. See Consolidation Coal Co. v. Bailey, 467 F.2d 1124, 1126 (3d Cir. 1972).

197. J. Hellerstein, supra note 11 , at 620 ; Note, supra note 13, at 981-86.

198. Note, supra note 13 , at $993-94$.
} 